\title{
Niger: Poverty Reduction Strategy Paper Progress Report
}

Poverty Reduction Strategy Papers (PRSPs) are prepared by member countries in broad consultation with stakeholders and development partners, including the staffs of the World Bank and the IMF. Updated every three years with annual progress reports, they describe the country's macroeconomic, structural, and social policies in support of growth and poverty reduction, as well as associated external financing needs and major sources of financing. This country document for Niger, dated July 2003, is being made available on the IMF website by agreement with the member country as a service to users of the IMF website.

To assist the IMF in evaluating the publication policy, reader comments are invited and may be sent by e-mail to publicationpolicy@imf.org.

Copies of this report are available to the public from

International Monetary Fund $\bullet$ Publication Services

$70019^{\text {th }}$ Street, N.W. • Washington, D.C. 20431

Telephone: (202) 623-7430 • Telefax: (202) 623-7201

E-mail: publications@imf.org • Internet: http://www.imf.org

Price: $\$ 15.00$ a copy

\section{International Monetary Fund \\ Washington, D.C.}



REPUBLIC OF NIGER

OFFICE OF THE PRIME MINISTER

\section{POVERTY REDUCTION STRATEGY PROGRESS REPORT}

(TRANSLATED FROM FRENCH)

July 2003 


\section{TABLE OF CONTENTS}

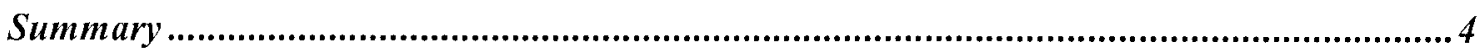

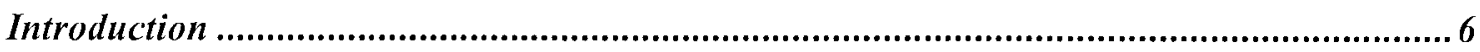

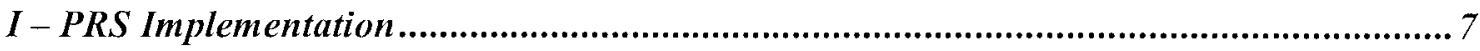

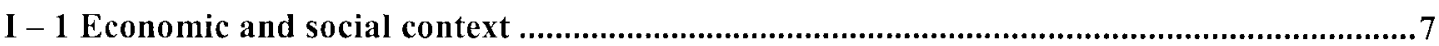

I - 2 General framework of the strategy: Specificity of the PRS ................................................. 8

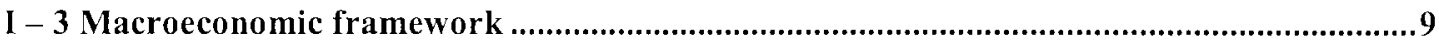

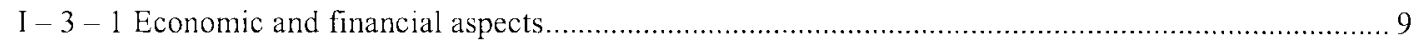

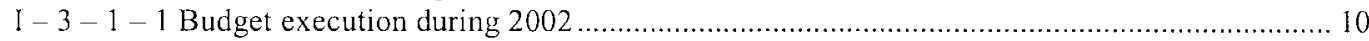

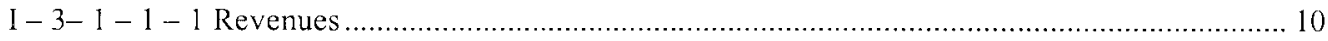

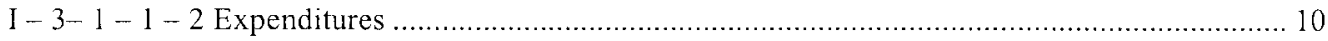

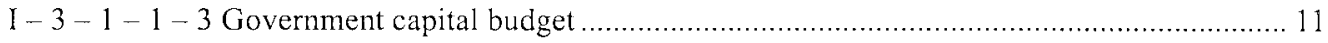

I $-3-1-1-4$ The use of HIPC Initiative resources ……..................................................... 13

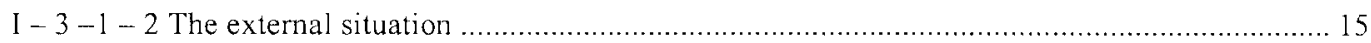

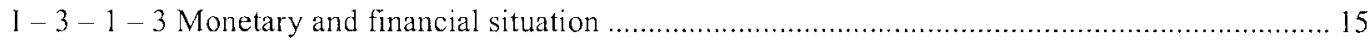

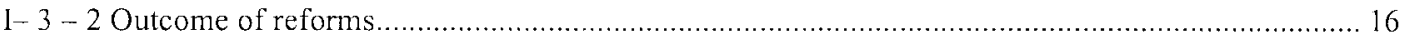

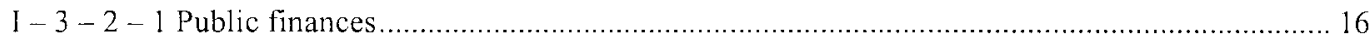

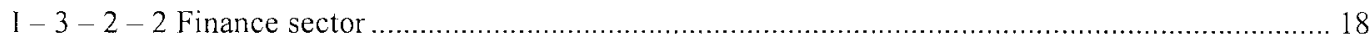

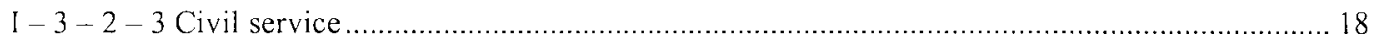

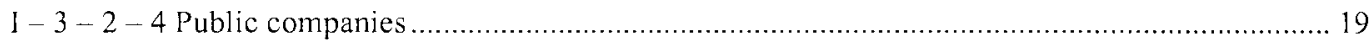

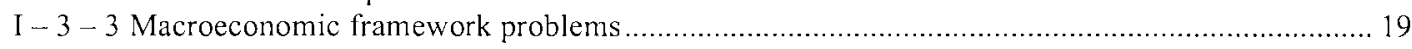

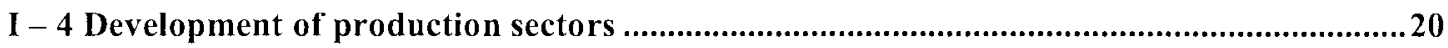

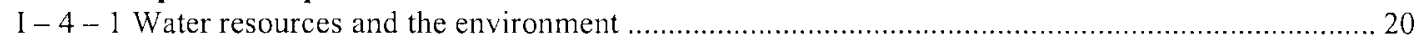

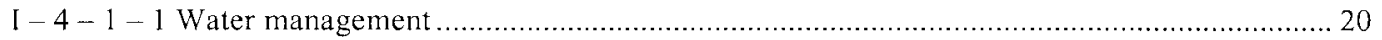

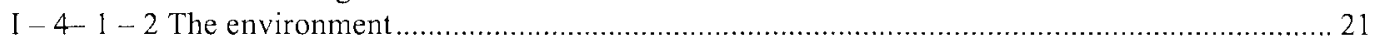

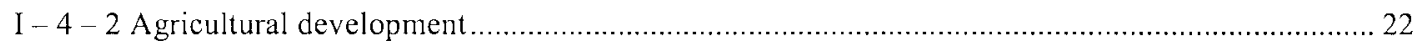

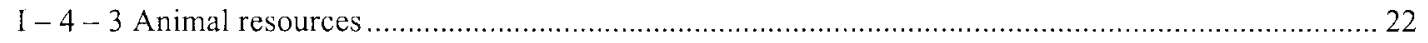

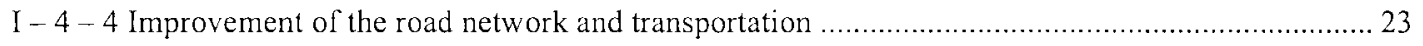

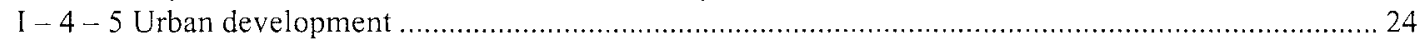

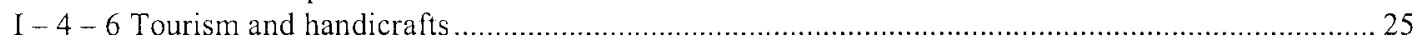

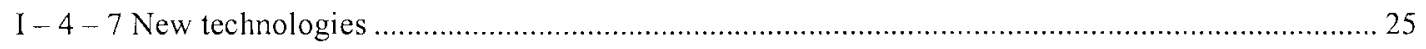

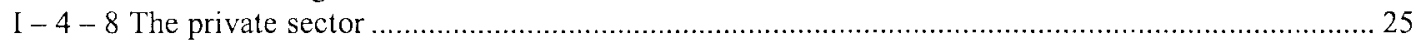

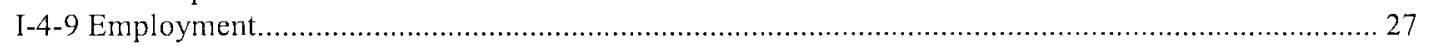

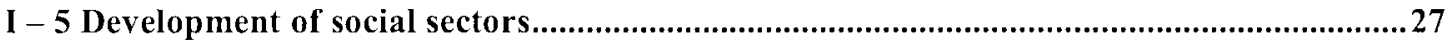

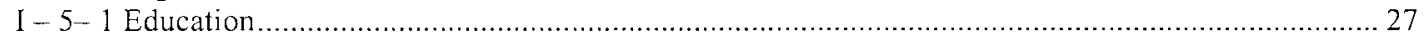

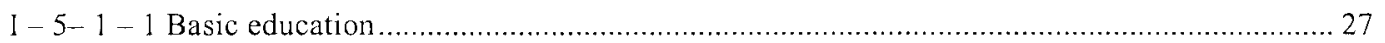

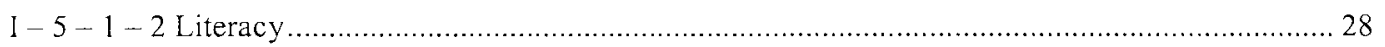

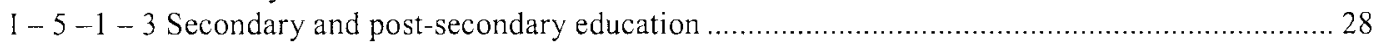

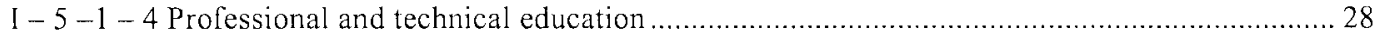

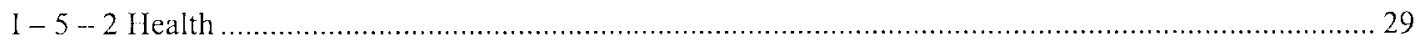

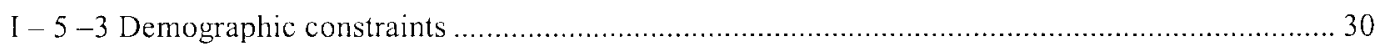

I - 6 Good governance, decentralization and strengthe ning capacities .......................................31

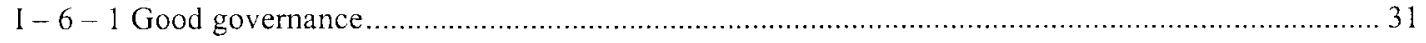

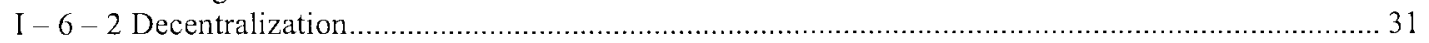

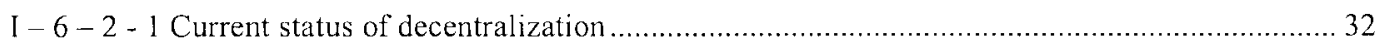

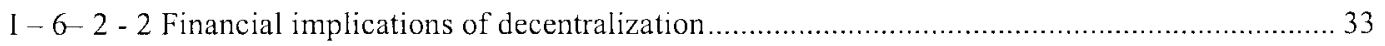

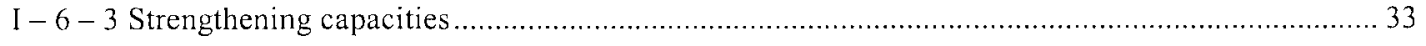

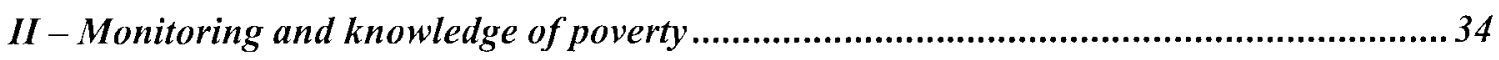

II - 1 Monitoring mechanism........................................................................................................34

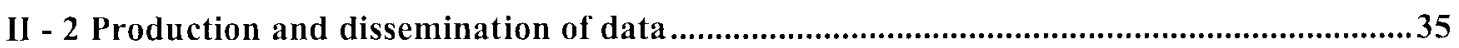




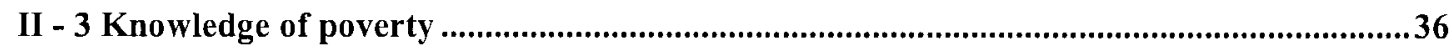

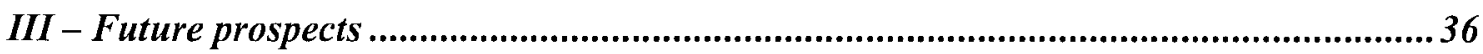

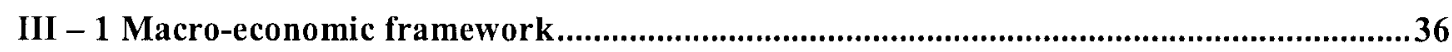

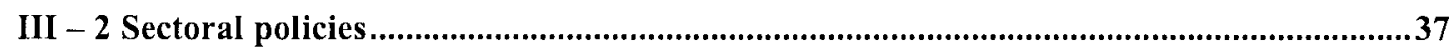

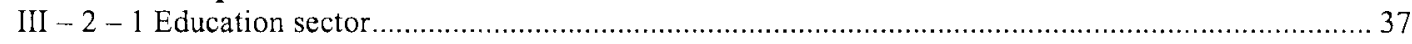

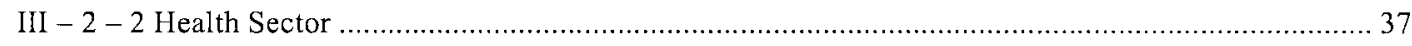

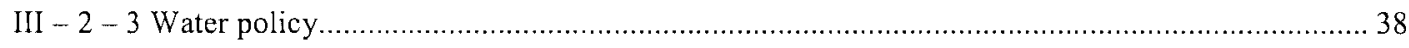

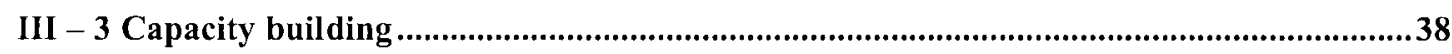

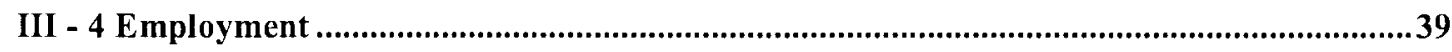

III - 5 Monitoring and evaluation.............................................................................................. 40

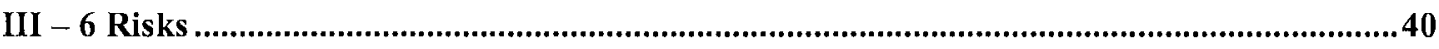

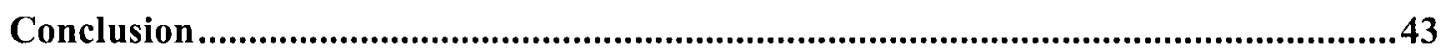




\section{Summary}

This is a report on the implementation of the Poverty Reduction Strategy (PRS), covering the period from January 2002 to June 2003. One of the pillars that support the PRS is the Special Program of the President of the Republic, financed by resources freed by the HIPC Initiative. The PRS has been implemented in a difficult internal environment caused by the persistent financial problems facing the government, social problems and crisis in the region, whose effects were felt during the last quarter of 2002.

In spite of these problems, this report indicates that the overall economic and financial situation of Niger has improved in recent years. This has allowed the macroeconomic framework to begin to stabilize. The results have benefited from the contributions of economic restructuring programs implemented since the late 1980s. However, the substantial improvements notwithstanding, growth in per capita income (1 to 2 percent on average from 1994 to 2001) is still inadequate to prevent social conditions from deteriorating or to contribute to a significant reduction in poverty.

Performance in the implementation of the economic and financial program was generally satisfactory. In fact, all performance criteria and benchmarks at end-December 2002 were respected except for non-accumulation of external payment arrears and the payroll benchmark. This positive overall result is due essentially to:

$\checkmark$ strengthened budgetary discipline from the first quarter of 2002; and

$\checkmark$ expenditure reduction and reallocation measures in the second half of the year.

The implementation of the President's Special Program financed by resources made available by the HIPC Initiative, which is an important component of the PRS, has also shown highly satisfactory progress.

With regard to the structural reforms, major progress was achieved in 2002, especially in the budgetary area. In fact, the introduction of a new budget nomenclature and a new charter of public accounts for the government and their use in the preparation of the 2003 Finance Law were effective. Nevertheless, the structural reform program remained affected by the limited institutional capacity, contributing to new delays in implementing reforms. In particular, long delays in mobilizing technical assistance prevented the completion of the anticipated improvement in debt management.

The territorial administration reform process, underway for several years, is experiencing a very significant advance in terms of design. Following the recent adoption of the main laws on decentralization, review of the implementation strategies for the new administration option and territorial management is continuing.

In the social sectors, encouraging results were obtained in education. The Ten-Year Education Program was finalized, creating a solid basis for the implementation of actions in this sector. According to the most recent estimates, the basic enrolment rate was 41.7 percent in 2002 compared to 37.3 percent in 2001 . These results are due to the efforts of the government in recruiting volunteer teachers and building and equipping of classrooms. The government also adopted a national policy for higher education. 
In the health sector, the 2001-11 Strategic Orientations for Health Development were adopted. These set the priorities for health, creating the foundation for the Ten-Year Health Plan currently being developed. It should be noted, however, that problems (such as personnel recruiting) have handicapped the operations of the services, so that the objectives set for this sector have not been reached.

This report also discusses population issues, the inadequacy of statistical data and the weakness of information on sources of growth. In fact, the current demographic growth rate, estimated at 3.1 percent, remains a major concern for the implementation of the PRS and a limiting factor for achieving the Millennial Development Goals. Finalization of the study of sources of growth could provide better knowledge of opportunities in sectors of production in Niger and provide employment.

In addition, the weaknesses of the national statistical apparatus create an obstacle for the analysis of the various PRS implementation monitoring indicators. The problem is less pronounced in some areas, due in part to reforms that have been undertaken (public finances, education). However, in the health sector, the constraints that continue to impede data collection and analysis constitute a major factor in the system's dysfunction. It must also be acknowledged that the data on the monetary indicators of poverty are outdated (the National Household Consumption Survey dates from 1989). It is imperative to mobilize the resources necessary to conduct a new national survey of household consumption, in order to update the monetary indicators of poverty. In fact, if this survey is not conducted, the PRS update will be compromised.

Likewise, the report lists the prospects for 2003-04. These prospects involve the pursuit of reforms, stabilization of the macroeconomic framework, implementation of a monitoring and evaluation system, and increasing the knowledge of poverty through studies and surveys to be conducted by the National Statistics Institute.

Finally, the report highlights a number of major activities, which include:

$\checkmark$ strategy internalization;

$\checkmark$ the donors' Forum on the PRS in June 2003, which made it possible to confirm the government's desire to pursue the PRS implementation and the commitment of development partners to assist Niger in this process;

$\checkmark$ the pursuit and finalization of sector strategies, in particular the finalization of the Rural Development Strategy and the strategic orientations of the health policy;

$\checkmark$ discussion of the harmonization action plan.

In sum, in spite of the macroeconomic results obtained thanks to reforms, efforts are still required in certain areas, in particular, improved knowledge of the sources of growth, evaluation of the health sector (such as the study on the impact of health expenses on poverty), and population issues. 


\section{Introduction}

In January 2002, the government of Niger adopted the Poverty Reduction Strategy (PRS). This document was positively evaluated by the Boards of Directors of the International Monetary Fund (IMF) and World Bank in February 2002. Development of the PRS took over from the planning exercises and the structural adjustment programs. The PRS process is characterized by its originality, which lies in the systematization of the participatory process, the consideration of poverty in its various dimensions as the focal point of its analysis, and the coherency of the selected objectives with the action programs adopted at various world development summits.

The PRS is the sole reference framework for the whole economic and social policy of the government of Niger. It pursues the objective of sustainable and poverty reducing growth through commitments and provisions structured around its four strategic components, i.e.:

$\checkmark$ Sustained and Sustainable Economic Growth: this component is based on a policy of macroeconomic stability and low inflation;

$\checkmark$ Development of Productive Sectors: this is the central core of the strategy in terms of income generation and growth. It stresses the potential of the rural sector (agriculture and herding), especially land development from the use and control of surface water resources, and the locomotive role that the private sector must play in development;

$\checkmark$ Development of Basic Social Services reflects the commitments made at the Millennium Summit in September 2000, which were taken up and integrated in the Strategy. It is based on a better redistribution of the revenues from growth to benefit the poor, in order to enable the main poverty indicators to evolve positively and substantially by 2015 ; and

$\checkmark$ Promotion of good governance, strengthening human and institutional capacities and decentralization: this component stresses the quality of the human resources and the actions to be conducted to assure good political, administrative, economic and local governance and the creation of conditions that will allow sound management of the public assets.

The PRS is based on three fundamental principles that assume:

$\checkmark$ taking gender into account;

$\checkmark$ redefining the roles of the various stakeholders (government, population, civil society, private sector and development partners); and

$\checkmark$ promoting good governance.

Moreover, the alignment of Niger's development partners' program with the PRS orientations reflects its uniting quality and the effectiveness of the coordinating role played by the government.

Within the framework of the PRS, the government has adopted, as its principal objective, the reinforcement of the participatory process engaged while the strategy was being developed. This is done by means of PRS internalization and ownership workshops, knowledge of the sources of growth, development of a Rural Development Strategy (RDS) and creation of conditions that make it possible to establish an effective monitoring and evaluation system. 
This report is intended to review the implementation of the PRS. It offers an analysis of the measures, actions and reforms undertaken in priority sectors, and the prospects for better achieving PRS goals.

The development of this report results from a consultation among the various stakeholders (administration, elected officials, civil society, private sector and development partners) as part of the consolidation of the participatory process undertaken. It is organized in three (3) parts.

- The first part reviews the progress achieved in the implementation of priority action plans for each of the four components of the strategy;

- The second part presents monitoring and knowledge of poverty; and

- The third part describes the prospects for government actions in the context of the fight against poverty, in order to remedy the shortcomings and problems identified during implementation.

\section{I - PRS Implementation}

\section{I - 1 Economic and social context}

The economic and social context of Niger is characterized by constraints of various kinds. These include:

$\checkmark$ a harsh climate;

$\checkmark$ generalized poverty;

$\checkmark$ a precarious economic and financial situation;

$\checkmark$ very low social indicators;

$\checkmark$ strong demographic growth, estimated at 3.1 percent in 2001;

$\checkmark$ inadequacy of the infrastructures for the internal and external reduction of isolation;

$\checkmark$ an embryonic modern private sector, subject to intense competition and handicapped by the activities of an informal sector whose dimensions are poorly understood; and

$\checkmark$ a nascent democracy, often accompanied by social unrest.

Economically, 2002 was marked by the Côte d'Ivoire crisis, whose negative effects were experienced in terms of trade circuits. The impact of this crisis on Niger's economy was generally minimal.

The improved performance in 2002 due to the recovery of economic activities and the restoration of public finances generated protests from various social partners. These demands were essentially embodied in (i) the rejection by the business community of the new tax measure in the 2002 Budget Law related to tax installments on the industrial and commercial profits of re-export operations; (ii) numerous strikes instigated by the unions in the private sector to obtain a reduction in income taxes; (iii) a mutiny by some elements of the armed forces in August 2002; and (iv) strikes initiated by a number of workers' union to force wage increases.

To effectively manage all these problems, the government set up a permanent process for dialogue and negotiation with its social partners. In addition, it began a process to modernize the armed forces, which should materialize following an audit commissioned for this purpose. It should be specified that this constructive dialogue approach applied by the government does not challenge the ownership of the three-year program 2000-03 or the goals of the 
poverty reduction strategy. Instead, it is a pragmatic and conciliatory approach that seeks to engage the whole population in supporting the goals of the program while discussing certain practical conditions for achieving the hoped-for results.

\section{I- 2 General framework of the strategy: Specificity of the PRS}

To consolidate the participatory process and implement the communications plan, the Permanent Secretariat of the PRS organized in May, August, September, and October 2002 an extensive campaign for the internalization and adoption of the PRS, targeting central, regional and sub-regional players.

Accordingly, a series of workshops was organized in Niamey for the Secretary Generals of the ministries, Directors of Studies and Programming and some high level officials, as well as members of parliament, media, civil society organizations such as associations, unions, and nongovernmental organizations (NGOs).

Thereafter, the process was continued throughout the country. At the regional and subregional levels, the internalization of the PRS was preceded by strengthening the capacities of some members of the regional steering committees.

Overall, the lessons drawn from this internalization campaign include:

$\checkmark$ a strong mobilization of authorities and civil society through their effective participation in all meetings;

$\checkmark$ a good appreciation of the participatory approach, enabling all players not only to express their views on the economic and social development programs, and participate in their monitoring and evaluation, but also to define their role in implementation; and

$\checkmark$ a greater involvement by women and young people (the population fraction most vulnerable to impoverishment).

It should be noted that a number of recommendations were formulated, including the following:

$\checkmark$ continuation of internalization at the local level;

$\checkmark$ translation of the PRS into the national languages; and

$\checkmark$ the need for greater mobilization of internal and external resources for a lasting fight against poverty.

The second major general activity was holding a forum of development partners on the PRS in Niamey on June 7 and 8, 2003. Through this innovative approach, the government of the Republic of Niger continued its political dialogue with the international community.

The expectations of the government from the forum were:

$\checkmark$ confirmation by the development partners of their determination to support the PRS and the practical means for its implementation through a new partnership framework;

$\checkmark$ harmonization of the conditions, procedures and methods of intervention by the development partners;

$\checkmark$ search for effective aid coordination and the introduction of consensual review procedures; and 
$\checkmark$ mobilization of additional financial resources.

The Development Partners Forum was an opportunity for the government to present to all its partners the major challenges of the PRS, the problems raised by its implementation and the support expected from the international community. Beyond the dynamics of mobilizing resources, the conclusions of the Forum reaffirmed the consensus between the government of Niger and all its partners on the objectives of the strategy, its implementation and its monitoring and evaluation.

At the end of the Forum, the partners reviewed the means already available to assist the government in the execution of its program to fight poverty. And while acknowledging the efforts deployed by the authorities, they agreed to program their support based on the PRS and its sector and thematic programs.

In addition, they recommended that the financing of the PRS be sought for and facilitated through budgetary support of donor organizations whose charters allowed them to do so, and as soon as fiduciary control conditions are met.

The partners also declared that they were favorable to a reorientation of ongoing projects, where necessary, in order to improve their coherence and execution within the PRS.

\section{I - 3 Macroeconomic framework}

Reduction of poverty necessarily proceeds by way of sustained and sustainable economic growth in a restructured and stable macroeconomic framework and a competitive economy. In fact, macroeconomic stabilization is the foundation on which the implementation of the Poverty Reduction Strategy stands. The government will pursue with determination its economic and financial program covering the period from October 1, 2000 to September 30, 2003. The main goal of this program is an adjustment of public finances to correct budget imbalances, the payment of domestic payments arrears and the implementation of structural reforms. At the end of two (2) years of execution, the conclusions of reviews confirm that the program is being conducted satisfactorily.

\section{I-3-1 Economic and financial aspects}

2002 was characterized by a rate of economic growth estimated at 3 percent, due to a favorable economic context. This rate is due to the good harvest resulting from good rainfall during 2001 and 2002, a vibrant private sector, and the implementation of the President's Special Program.

In fiscal 2002, the economic and financial situation described in the provisional table of the government's financial operations (in the annexes), shows an improvement in the main budget balances. For example, the overall deficit (on a commitments basis, excluding grants) declined from 8.4 percent of GDP in 2001 to 7.7 percent of GDP in 2002, and the basic deficit shrank by 1.8 percentage points of the GDP to 2.1 percent in 2002, compared with 3.9 percent of GDP in 2001. This improvement in budget balances is the consequence of a major increase in total revenues and an effort to control and limit budget expenses in spite of the harmful effects of the Côte d'Ivoire crisis.

Inflation stood at an annual average of 2.6 percent in December 2002, compared with 4 percent in December 2001 and 2.9 percent in December 2000. 
With regard to debt, Niger should reach the completion point of the enhanced Initiative for Highly Indebted Poor Countries (HIPC Initiative), expected before the end of 2003, and thereby benefit from supplemental debt relief. This could guarantee debt sustainability and the financing of the anti-poverty actions that are part of the PRS. The government should also maintain its efforts at clearing its domestic debt over the next few years, in order to guarantee development of the private sector.

\section{I - 3 - 1 - 1 Budget execution during 2002}

\section{I - 3-1-1 - 1 Revenues}

In spite of disruptions of both internal and external origin during the $3^{\text {rd }}$ quarter of 2002 that affected the economy of Niger, total budget revenues collected during 2002 amounted to CFAF 160.9 billion, compared with 132.8 billion in 2001, that is an increase in the order of 21 percent. This growth is due to a strong improvement in customs revenues and revenues from other categories. These results were obtained by the generalization of the use of the possibilities offered by the Tax Identification Number (NIF) and better working conditions for tax administration personnel, which allowed a significant reduction in tax fraud and a better control over tax exemptions while expanding the tax base.

In addition, the intensive mobilization of all tax services allowed an improvement in the ratio of revenues to GDP, thus moderating the revenue consequences of internal and external disturbances and the impact of the Côte d'Ivoire crisis. In fact, budget revenues rose from 8.6 percent of GDP in 2000, to 9.3 percent in 2001 , and 10.6 percent in 2002 , which represents an annual variation of 8.1 percent in 2001, and 14 percent in 2002 .

Table 1: Trends in main revenue items (in billions of CFA francs)

\begin{tabular}{|l|r|r|r|r|}
\hline & \multicolumn{1}{|c|}{$\mathbf{2 0 0 0}$} & \multicolumn{1}{|c|}{$\begin{array}{c}\text { 2001 } \\
\text { est. }\end{array}$} & \multicolumn{1}{c|}{$\begin{array}{c}\text { P003 } \\
\text { Plan }\end{array}$} \\
\hline Total revenues & $\mathbf{1 1 0 . 1}$ & $\mathbf{1 3 2 . 8}$ & $\mathbf{1 6 0 . 9}$ & $\mathbf{1 6 7 . 8}$ \\
\hline Tax revenues & 102.8 & 125.5 & 144.6 & 158.5 \\
\hline Taxes on foreign trade & 58.5 & 64.8 & 82.9 & 81.2 \\
\hline Taxes on goods and services & 20.6 & 30.9 & 30.6 & 40.2 \\
\hline Taxes on income and profits & 18.0 & 22.6 & 23.1 & 27.0 \\
\hline Other tax revenues & 5.7 & 7.2 & 7.9 & 10.1 \\
\hline Non-tax revenues & 3.8 & 4.1 & 3.8 & 2.3 \\
\hline Annual budg. rev. + spec. accts. & 3.5 & 3.2 & 4.1 & 4.0 \\
\hline Compensation revenues & 0.0 & 0.0 & 8.4 & 3.0 \\
\hline
\end{tabular}

Source: DEFR/DGP Ministry of Finance and Economy.

\section{I - 3-1 - 1-2 Expenditures}

Total expenditure and net lending amounted to CFAF 278.1 billion in 2002, compared with CFAF 245.6 billion in 2001, up some 13.2 percent. This increase is due to an increase in capital outlays of 31 percent (specifically those financed by external resources and the HIPC Initiative). Current expenditure grew only 2.8 percent. The analysis of the ratio of expenditures to GDP shows that current budget expenditure, which represented 12.4 percent of GDP in 1999, stabilized at 11 percent of GDP between 2000 and 2002. In particular, 
payroll was reduced from 4 percent of GDP en 1999, to 3.5 percent in 2001 and 3.7 in 2002. The proportion of revenues it absorbs went from 50.3 percent in 1999 to 50.4 percent in 2000 , 40.1 percent in 2001 and 38.3 percent at the end of 2002, according to current estimates.

Table 2: Trends in main expenditure items

(in billions of CFA francs)

\begin{tabular}{|l|r|r|r|r|}
\hline & \multicolumn{1}{|c|}{$\mathbf{2 0 0 0}$} & \multicolumn{1}{c|}{$\mathbf{2 0 0 1}$} & \multicolumn{1}{c|}{$\begin{array}{c}\text { 2002 } \\
\text { est. }\end{array}$} & \multicolumn{2}{c|}{\begin{tabular}{l} 
Plan \\
\hline Expenditures
\end{tabular}} & $\mathbf{2 1 4 . 3}$ & $\mathbf{2 4 5 . 6}$ & $\mathbf{2 7 8 . 1}$ & $\mathbf{3 0 3 . 9}$ \\
\hline Total current expenditure & $\mathbf{1 4 3 . 8}$ & $\mathbf{1 5 7 . 4}$ & $\mathbf{1 6 1 . 8}$ & $\mathbf{1 6 3 . 3}$ \\
\hline Current budget expenditure & 138.5 & 147.1 & 153.7 & 154.8 \\
\hline Wages and salaries & 51.8 & 50.4 & 55.3 & 57.3 \\
\hline Materials and supplies & 39.9 & 44.2 & 48.7 & 44.7 \\
\hline Subsidies and transfers & 24.0 & 28.1 & 30.3 & 41.0 \\
\hline Interest payable & 21.6 & 25.4 & 22.6 & 17.5 \\
\hline External debt & 19.6 & 24.1 & 21.2 & 16.1 \\
\hline Internal debt & 2.0 & 1.3 & 1.5 & 1.4 \\
\hline Annexed budgets /special accounts & 5.3 & 10.3 & 8.1 & 8.5 \\
\hline Capital expenditure and net lending & $\mathbf{7 0 . 5}$ & $\mathbf{8 8 . 1}$ & $\mathbf{1 1 6 . 3}$ & $\mathbf{1 4 0 . 5}$ \\
\hline Capital expenditures & 73.6 & 89.0 & 116.5 & 140.5 \\
\hline as a ratio of budget resources & 8.1 & 25.1 & 27.2 & 35.5 \\
\hline as a ratio of external resources & 65.5 & 63.9 & 89.4 & 105.1 \\
\hline of which: HIPC resources & 0.0 & 7.9 & 9.8 & 16.5 \\
\hline Net lending & -3.1 & -0.8 & -0.2 & 0.0 \\
\hline
\end{tabular}

Source: DFER/ DGP Ministry of Finance and Economy.

The stock of domestic payments arrears was reduced by more than CFAF 50 billion between 1999 and 2002 in net terms. This reduction in arrears benefited the "small creditors", government employees, suppliers, and banks.

Table 3: Highlights of current budget execution for 2000-03 (In billions of CFA francs)

\begin{tabular}{|l|r|r|r|}
\hline \multicolumn{1}{|c|}{ Structures } & Outcome 2000 & Outcome 2001 & \multicolumn{1}{c|}{ Outcome 2002 } \\
\hline Social services & 42.7 & 46.0 & 56.3 \\
\hline Production services & 2.7 & 3.8 & 4.1 \\
\hline Infrastructures & 0.8 & 2.4 & 3.3 \\
\hline Other & 85.8 & 135.8 & 111.7 \\
\hline TOTAL & $\mathbf{1 3 2 . 0}$ & $\mathbf{1 8 8 . 0}$ & $\mathbf{1 7 5 . 4}$ \\
\hline
\end{tabular}

Source: DGB Ministry of Finance and Economy.

\section{I - 3-1-1-3 State Investment Budget}

The State Investment Budget is the main instrument for the implementation of the economic, financial and social policy of the government. Since 2000, its execution has always put special emphasis on projects responding directly to the concerns of the poor, in particular the social sectors. The following chart clearly illustrates this situation. The 2002 investment budget was voted for a total envelope of CFAF 133.685 billion including all sectors and sources of financing, or an increase of 15.29 percent relative to the 2001 investment budget. 
Table 4: Execution of the Government Capital Expenditure Budgets, 2000-02 (in billions of CFA francs)

\begin{tabular}{|l|r|r|r|r|}
\hline & 2000 & 2001 & 2002 & 2003 \\
\hline Production sectors & 19.3 & 24.4 & 26.8 & 35.2 \\
\hline Social sectors & 31.4 & 27.2 & 37.4 & 100.6 \\
\hline Economic infrastructure & 13.3 & 4.3 & 15.6 & 19.3 \\
\hline Other Total & 9.6 & 26.7 & 24.2 & 29.4 \\
\hline \multicolumn{1}{|c|}{ Total } & 73.6 & 82.6 & 104.0 & 184.5 \\
\hline
\end{tabular}

Source: Investment Financing Division.

As the above table indicates, the total amount of outlays under the 2002 investment budget is CFAF 104 billion (of which CFAF 90.2 billion was budgetized and 13.8 billion was outside the budget) or a credit consumption rate of 77.8 percent, compared to 64.2 percent for fiscal 2001.

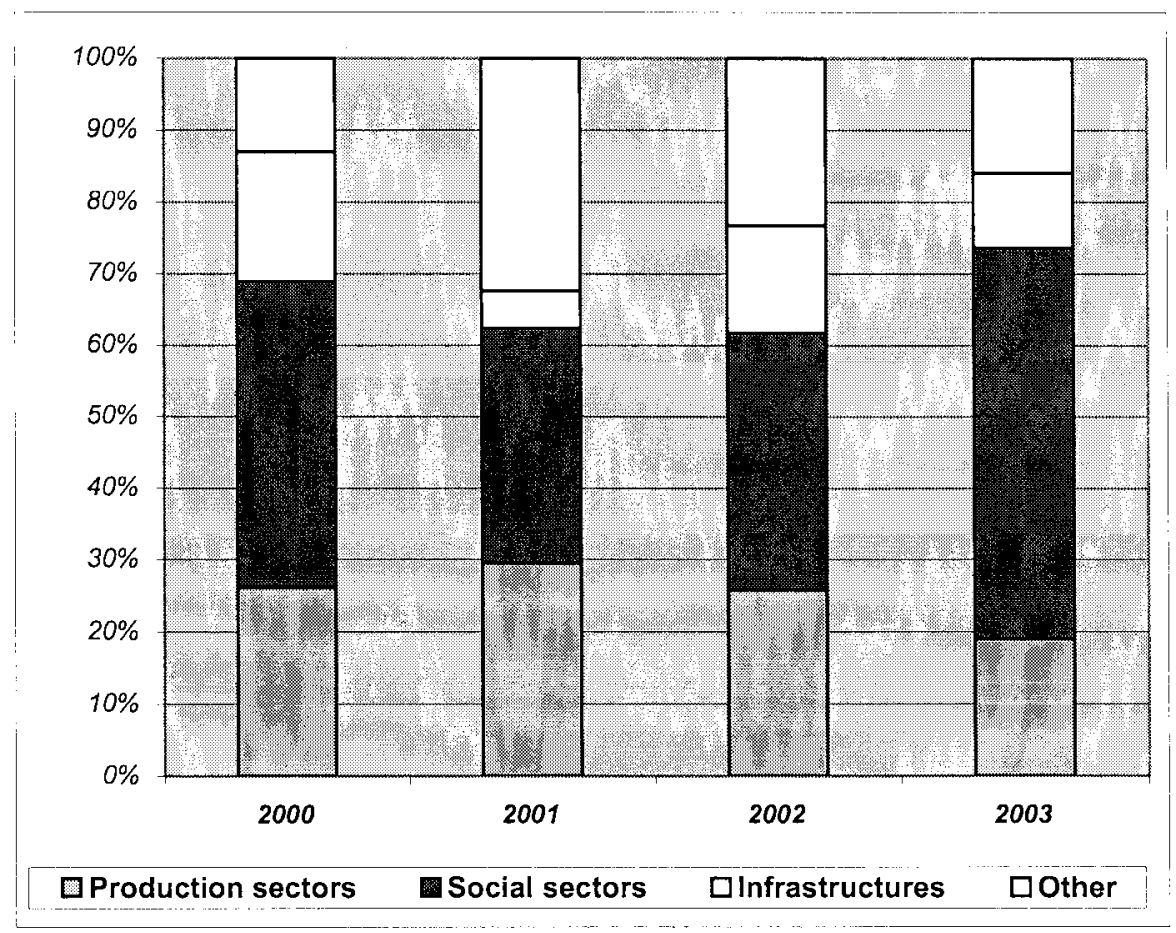

Problems were identified with respect to the implementation of the investment budget. Among these problems are factors that limit capital budget implementation performance:

$\checkmark$ problems related to obtaining information on the execution of direct management projects: credits for payments of projects of this nature represent generally more than 46 percent of non-reimbursable assistance;

$\checkmark$ inadequacy of information on potential upcoming resources from certain development partners resulting in inadequacies in the scheduling and budgeting of public investments;

$\checkmark$ the complexity and slowness of public procurement procedures, which, however, were reformed in 2002 and resulted in the drafting of a public procurement code; and 
$\checkmark$ the inadequacy of the human and financial resources in the Investment Financing Directorate (DFI) in ensuring better financial and physical tracking of public investment expenditures.

To eliminate these problems, the following solutions can be considered:

$\checkmark$ generating awareness in development partners and involvement of public authorities to facilitate the access to information and efficient tracking of public investment expenditures;

$\checkmark$ control and improvement of public procurement procedures by training public administration agents and other involved parties in the procedures of the various donors regarding disbursement and public procurement; and

$\checkmark$ reinforcement of the capacities of the technical services responsible for financial and physical monitoring of public investment expenditures.

\section{I $-3-1-1-4$ The use of HIPC Initiative resources}

The government has taken the option of using the HIPC Initiative resources (see Box 1) to build social and productive infrastructures. This commitment is implemented through the Special Program of the President of the Republic (SPPR), which is intended to guarantee greater accessibility to basic social services and create conditions for production to recover. The overall cost of the program's implementation (in terms of payment orders) is estimated at CFAF 18.05 billion and is entirely covered by HIPC Initiative resources within the framework of the 2001 and 2002 budgets.

The 2002 budget entry for these actions is CFAF 10.209 billion compared to 8.782 billion in 2001, reflecting an increase of CFAF 1.4 billion in expenditures compared to the previous fiscal year.

\section{a) Financial result}

Table 5: Situation of HIPC Credits (in billions of CFA francs)

\begin{tabular}{|l|r|r|r|r|r|r|}
\hline & \multicolumn{2}{|c|}{2001} & \multicolumn{2}{c|}{ 2002 } & \multicolumn{2}{|c|}{ 2003 } \\
\cline { 2 - 7 } & Budget & Outcome & Budget & Outcome & Forecast & $\begin{array}{c}\text { Outcome } \\
\text { (June 2003) }\end{array}$ \\
\hline Water resources & 4.5 & 4.2 & 4.7 & 4.5 & 9.2 & 3.7 \\
\hline Health & 2.1 & 2.1 & 3.0 & 2.8 & 4.7 & 1.5 \\
\hline Education & 1.7 & 1.7 & 1.9 & 1.9 & 3.7 & 1.6 \\
\hline Other & 0.5 & 0.1 & 0.6 & 0.1 & 1.8 & 0.7 \\
\hline Total & $\mathbf{8 . 8}$ & $\mathbf{8 . 1}$ & $\mathbf{1 0 . 2}$ & $\mathbf{9 . 3}$ & $\mathbf{1 9 . 4}$ & $\mathbf{7 . 6}$ \\
\hline
\end{tabular}

Source: Ministry of Economy and Finance, and Interim Evaluation Report.

About 95 percent of the funds planned for the execution of all of the projects were used. There were no reports of major problems with respect to the management of funds, which consisted in delegating credits to the regions. 


\section{Box 1. The Special Program of the President of the Republic}

The Special Program is an initiative of His Excellency MAMADOU TANDJA, President of the Republic, Chief of State, that takes place in the context of the implementation of the PRS and is supported by appropriate use of the HIPC resources. Started in 2001, it must be considered an approach to seeking significant improvement in the living conditions of the people of Niger.

By funding the expansion of health coverage, increases in the rate of school enrolment and improvement in the output of the rural economy, the Special Program is intended to promote growth in the economic sphere for the poor, increasing incomes and creating jobs for young people through vocational training.

It is important to note that the special Program supports existing development programs. Its design and implementation follow the requirements of consistency and synergy necessary to assure greater effectiveness and a positive impact from actions affecting of the poor.

The prospects for future steps are good because there will be innovations, in addition to the measures already considered as part of the first phase. It will be a matter of developing the three-way cooperation between the government, which is the principal regulator and organizer, the donors and civil society. Creation of this cooperation and the greater involvement of civil society should enhance public interest in the program, contributing to improving its effects even further and effectively fighting poverty. The effectiveness of the three-way cooperation will also serve to ensure transparency in the management of funds and reflect the attachment to quality governance. Finally, adoption of a participatory approach, which would broadly involve society, may also increase the effectiveness of the next phase and thus help bring about a greater reduction of poverty.

Plans for this new phase, which has just been launched, call for 1,000 classrooms, 1,000 health units, and 1,000 wells, to be completed by projects for building mini-dams and bodies of water and rural tracks and providing livestock support by the development of nearby veterinarian services. The promotion, execution, monitoring and sustainability of these projects will continue to require the involvement and participation of local residents. Moreover, the share of capital expenditures devoted to social sectors (education, health and water resources), besides those financed by the HIPC Initiative, represents nearly half of the total in 2003.

The few problems associated with the financial aspect of the program are essentially due to the failure to take specific aspects of each region into account in the expenditure forecasts; some regions are less isolated than others, so that the cost of acquisition some materials is relatively low. Appropriate weighting factors were defined and applied to each region.

\section{b) Physical achievements}

The table below gives the level of the physical achievements of the first phase of the President's Special Program at the national level in 2001 and 2002.

It can be seen that once the program was launched, most of the planned projects were completed. Since this first phase was a test, it may suggest interesting prospects given results obtained so far, as well as measures put in place to increase the efficiency of its implementation.

In addition to works completed, the implementation of the President's Special Program has allowed the distribution of CFAF 500 million in the form of loans to 1,450 women's groups (about 45,000 women). 
Table 6: Achievements of the President of the Republic's Special Program in 2001-02

\begin{tabular}{|l|c|c|c|}
\hline \multicolumn{1}{|c|}{ Segment } & Forecast & Outcome & Variance \\
\hline Health clinics & 1000 & 955 & -45 \\
\hline Equipment & 1000 & 955 & -45 \\
\hline Recruiting of nurses & 1000 & 955 & -45 \\
\hline Classrooms & 1000 & 1003 & -45 \\
\hline Equipment & 1000 & 1003 & +3 \\
\hline Recruiting of teachers & 1000 & 1003 & +3 \\
\hline Mini-dams & ) & 46 & ) \\
\hline Irrigation sills & ) 100 & 42 & )-5 \\
\hline Hydro-farming facilities & ) & 6 & ) \\
\hline Protection dikes & ) & 1 & ) \\
\hline Grassland wells & 120 & 119 & -1 \\
\hline Village wells & 110 & 125 & +15 \\
\hline Drilling campaigns & 100 & 8 & -92 \\
\hline Market garden wells & 100 & 32 & -68 \\
\hline
\end{tabular}

Source: Office of the President of the Republic.

Nevertheless, some problems were identified. These problems, which are linked to the "experimental" nature of the undertaking, specifically involved:

$\checkmark$ inadequacy of the logistical and financial means, impeding the proper operation of controls;

$\checkmark$ inadequacy of technical studies prior to the construction of hydraulic structures, especially the mini-dams and the irrigation sills, although such studies are necessary for these structures to survive;

$\checkmark$ the poor inclusion of hydrogeological data in the construction of water supply points (village and grassland wells);

$\checkmark$ less involvement by beneficiary populations in the identification of their needs;

$\checkmark$ weak integration of regional characteristics in the determination of the costs of structures;

$\checkmark$ inadequate synergy among the central, regional and sub-regional structures responsible for monitoring and controlling the Program;

$\checkmark$ problems with equipping the health units and classrooms; and

$\checkmark$ slow pace at which funds became available.

The identification of problems associated with the implementation of the first phase of the program has offered lessons for the preparation of the second phase of the program.

\section{I - 3-1 - 2 The external situation}

External trade remains marked by the low diversification of the economy, which keeps the share of uranium at a very high level. With respect to exports, trade has developed positively since 1994 as a result of the monetary adjustment that helped exports become more competitive. They reached CFAF 250 billion in 2002 (16.5 percent of GDP) while imports were at CFAF 379 billion, or 25 percent of GDP in 2002.

\section{I-3-1-3 Monetary and financial situation}

Between December 2001 and December 2002, the monetary situation was characterized by: 
$\checkmark$ deterioration in foreign assets, which fell from CFAF 33.1 billion to CFAF 24.4 billion;

$\checkmark$ an increase of credit to the economy, which amounted to CFAF 75.8 billion in December 2002, compared with CFAF 66 billion in 2001. The main beneficiaries of this increase have been the industrial sector, public works and civil engineering, and trade and services. These credits are generally short term; and

$\checkmark$ a virtually stable money supply, which was CFAF 136.4 billion in December 2002 compared to CFAF 137 billion in 2001. Also noted is an increase in bank deposits of nearly CFAF 10 billion during the period.

\section{I- 3 - 2 Outcome of reforms}

Within the framework of implementation of the PRS, the government continued the implementation of reforms in the following priority areas:

1. Public finances;

2. Financial sector;

3. Public service;

4. Public companies sector.

\section{I-3-2-1 Public finances}

In public finances, actions involved the reinforcement of the tax administration in order to expand the tax base, improve tax collections, control current expenditures and improve the management of public debt, including domestic and external payments arrears. The government has also adopted other instruments to improve the management of public finances. These are the Government's Budget Nomenclature (NBE) and the Government's Charter of Public Accounts (PCE), adopted by Decree 2002-198 /PRN/MFE of July 26, 2002, and the new code for public procurement adopted by the National Assembly in October 2002.

\section{The Government's Budget Nomenclature (NBE) and the Government's Charter of Public Accounts (PCE):}

Implementation of this reform will contribute to strengthening the transparency and proper management of public finances and budget management overall. The 2003 Finance Law was prepared with the new nomenclature and its execution is effected within the framework of the new charter of public accounts.

Instituted by Directive 04/98/CM/WAEMU, the NBE has two major goals:

$\checkmark$ conform to the requirements of the regional regulatory framework of the West African Economic and Monetary Union (WAEMU); and

$\checkmark$ correct the inadequacies of the previous structure, which did not allow the uniform and consistent treatment of all government budget operations.

The Government Budget Structure now constitutes the accounting base for developing, adopting and executing the national budget.

The goals of the new charter of public accounts are: 
$\checkmark$ knowledge of the government's financial and accounting operations;

$\checkmark$ knowledge of the government's wealth;

$\checkmark$ control of budget and treasury operations (internal controls, parliamentary controls and jurisdictional controls); and

$\checkmark$ execution of economic and financial analyses that allow the preparation of ratios and balanced score cards.

\section{Reform of public procurement:}

This is designed to achieve the following specific objectives:

$\checkmark$ transparency in the awarding of contracts;

$\checkmark$ equality of access to public business by systematic recourse to competition;

$\checkmark$ efficiency of public expenditures, providing the government with a service that performs well;

$\checkmark$ respect for the principles of good governance; and

$\checkmark$ modernization of procedures.

Order 2002-007 of September 18, 2002 on the reform of the code for public procurement was ratified by the National Assembly on October 16, 2002. The reform of public procurement contains two components:

$\checkmark$ revision of the legal framework for negotiating contracts, instituting modern practices in line with international practices, including the future guidelines on the harmonization of policies and practices in procurement of the WAEMU;

$\checkmark$ institutional support for the structures responsible for managing public contracts in order to allow better application of regulations and increase efficiency.

Implementation of this new instrument remains handicapped by the shortage of means of the current Central Government Contracts Commission and the delay incurred in its conversion into a regulatory agency.

\section{Improvement of the expenditure chain}

The central computer system was renovated with the installation of a secure internal network providing real-time information on budget implementation. This offers the possibility for quickly elaborating balanced score cards and guaranteeing better control over how expenditures are made.

\section{Restoration of parliamentary and jurisdictional control}

The government has taken measures to continue the production of budget review laws and management accounts that was restored in 2000, starting with fiscal year 1997. The draft budget review law for 1997 was sent to the National Assembly after a statement of compliance was issued by the Chamber of Accounts and Budget Discipline. The budget review laws for fiscal 1998, 1999, and 2000 were voted by the National Assembly in December 2002. The 2001 budget review law was sent to the Chamber of Accounts in January 2003.

Furthermore, the Chamber of Accounts and Budget Discipline has been auditing the 
government's accounts, starting with fiscal year 1997. Their report is in the finalization stages. The effective implementation of the above measures has made it possible to create an economic and legal framework that is favorable to improving finances, guaranteeing greater transparency, and good budget discipline.

\section{I - 3-2 - 2 Finance sector}

Substantial progress was recorded in 2002 in reinforcing the financial sector. Among the most significant achievements are:

$\checkmark$ the financial situation of the Banque Commerciale du Niger (BNC) has become normalized since the release of CFAF 1.5 billion in October 2002 by the Libyan Arab Foreign Bank. This payment represents the share of capital that the State of Niger ceded to this bank with a possibility of buy-back, and the procedures for lifting provisional administration were begun in early 2003.

$\checkmark$ likewise, following two studies on the strategy for financing habitat and local communities, the government decided to release 90 percent of the capital of Crédit du Niger (CDN) before the end of the first half of 2003 and to freeze activities (except for collection) by the Caisse de Prêts aux Collectivités Territoriales (CPCT, a lending institution for local communities) while waiting for an improvement in market conditions that could result from a reorganization of the territorial communities.

$\checkmark$ on the other hand, the restructuring of Banque Islamique du Niger pour le Commerce et l'Investissement (BINCI) has not experienced a significant advance in 2002 because of delays in drafting an agreement with its main shareholders (DMI - Genève and Banque Islamique de Développement).

$\checkmark$ in the area of proximity financial intermediation, the financial and organizational audit of the main micro-finance institutions which was to start in early September 2002, was finally launched only in March 2003. Moreover, the actuarial audit of the National Social Security Fund (CNSS) could not be conducted in 2002 but will be done in 2003 with the support of the International Labour Office (ILO); and

$\checkmark$ finally, the implementation of the restructuring of the National Post Office and Savings Bank (ONPE) was postponed until 2003, as the result of delays in the planned studies of restructuring the postal division and the creation of a financial services subsidiary for the post office.

\section{I $-3-2-3$ Civil service}

The reforms engaged seek to control the number of employees and the payroll and modernize the government administration. In this framework, the following actions were carried out:

$\checkmark$ creation of an Advisory Committee on the Civil Service, bringing together representatives of the Administration and the unions on the new general status of the civil service, in order to harmonize the positions of the partners on the reform of the system of advancement, so that it will now occur on merit;

$\checkmark$ implementation of a record system automatically generating acts regarding the administrative management of the civil service; the system is already operational in certain technical sections of the Ministry of the Civil Service and Labor;

$\checkmark$ application of the integrated civil service and payroll file;

$\checkmark$ development of an integrated program to modernize the Nigerien Administration (PIMAN); 
$\checkmark$ application of the reform of budgetary posts in the health sector;

$\checkmark$ creation of an ad hoc committee to consider the transformation of the national pension fund (FNR) into an autonomous fund for financing civil servant retirements (CARFO); and

$\checkmark$ the development of multi-year plans for training government agents.

Despite this substantial progress, efforts remain to consolidate the payroll between wage payments, the financial effects of promotions, the salaries of contract workers and the social contributions of civil servants.

A new review has just begun for the creation of a status for agents in the civil service at the local level.

\section{I - 3-2 - 4 Public companies}

The reforms initiated relate to the finalization of the legal texts and the pre-qualification of bidders for NIGELEC. The privatization of NIGELEC through a management contract was delayed because the selection of pre-qualified bidders for the tender offer was not conclusive.

With respect to SONIDEP, the preliminary studies for its privatization by opening its capital were launched in July 2002. The first conclusions of these studies were discussed by an interministerial committee in November 2002. The pre-selection process started in July 2003 and the selection is expected by the end of August. The tender process could then begin in the first half of September.

As part of the reforms of the system for setting the prices for petroleum products, the government adopted Decree 2001-128/PRN/MC/I of July 26, 2001, defining the procedures for readjusting these prices in order to automatically and transparently responding to variations in international oil prices and the US dollar. The new procedure in force since August 1, 2001 has made it possible to achieve positive results (CFAF 6,612 billion of budget revenues from the tax on importing petroleum products for 2002). Furthermore, in June 2003, the government launched a study on the remunerations of the oil industry players.

\section{I - 3 - 3 Macroeconomic framework problems}

Despite the efforts deployed by the government to improve knowledge of economic data, some problems still impede the efficient use of instruments for improving the macroeconomic framework. These problems are essentially related to the mastery of certain forecasting tools, very specific knowledge of the sources of growth, measures to reinforce debt management and monitoring borrowing policies. The communications deficit was also noted as the process advanced, resulting in a lack of comprehension by certain partners.

In order to overcome these problems, a number of projects are under way. These are the study of the sources of growth, a draft of which is already available, and a study of the sustainability of the debt, whose results will be available before September 2003.

During this first year of implementation, the weaknesses in human resources were identified in a number of structures. 
The problem of coordinating aid remains a serious concern, with the government now reviewing ways to find a suitable solution with its partners. The ideas developed were shared with the partners at the PRS Forum in June 2003.

The problems linked to the mobilization of foreign financing led to budget adjustments. This situation constituted a handicap for the functioning of the public services, with resources mobilized being allocated to paying salaries, debt service and social services.

\section{I - 4 Development of production sectors}

The PRS assigns the rural sector (core production sector) the role as main engine of economic growth in Niger until 2015. For this purpose, a profound transformation of the rural sector is required, in order to build a base for economic growth that generates employment, sustained by a dynamic private sector.

To address this objective, the government began during 2001 to develop a Rural Development Strategy (SDR), which aims at making the PRS operational in this sector. The development of the SDR is a collaborative effort of the ministries of agricultural development, animal resources, water resources and anti-desertification and community development. The SDR document was validated at a national workshop held on June 2 and 3, 2003 in Niamey, and its finalization is planned for August 2003. The SDR will be submitted for government adoption by end 2003 .

The SDR has as its general objective to reduce the incidence of rural poverty from 66 percent to 52 percent by end- 2015 by creating the conditions for sustainable economic and social development, guaranteeing food security for the people and sustainable management of natural resources. Three strategic components have been defined:

$\checkmark$ promote economic opportunities for rural producers, in order to create the conditions for sustainable economic growth in rural areas;

$\checkmark$ mitigate risks, reduce food insecurity and manage natural resources in a sustainable manner to make living conditions more secure; and

$\checkmark$ strengthen the capacities of public institutions and rural organizations to improve the management of the rural sector.

It should be noted that the expected contribution of the rural sector to annual GDP growth has been set at 2 percent per year from 2001 to 2004 . This is an increase of 0.8 percent over the current contribution, which is about 1.2 percent. This will be necessary for accelerating economic growth and preserving economic stability in the medium and long term.

\section{I $-4-1$ Water resources and the environment}

Actions undertaken in these sub-sectors target knowledge about water resources, addressing water and water treatment needs, reinforcement of capacities, support for production sectors, combating desertification, management of natural resources and development of revenuegenerating activities. 


\section{I-4-1-1 Water management}

Activities conducted in this area seek to develop and implement policies and strategies for the sustainable management of water resources; the mobilization of sufficient human, financial and material resources for the implementation of these policies and strategies; the development and introduction of a national water management policy for urban, village and grazing land; the conservation and rational management of water resources; the improvement of the legislative framework governing activities relative to water resources and the enhancement of hydro-agricultural, urban, village and grazing land hydraulic infrastructures.

PRSP implementation has made it possible to conduct 18 drilling campaigns and create 108 village wells, 119 grassland wells and 32 market garden wells. In addition, 572 wells were built or renovated with funds from development partners.

Along with these achievements, activities to improve knowledge of water resources continued in hydrology, hydrogeology and geophysical campaigns and the physical, chemical and bacteriological quality control of water for human consumption.

\section{I - 4- 1-2 The environment}

The environment sector has experienced significant progress in terms of major concrete accomplishments as well as legislative and regulatory reforms.

With regard to production of all species of forest plants, some remarkable progress has been observed. A major increase in seedling production was recorded (18 million seedlings in 2002 , of which 9 million in the context of the gum tree program, compared to 14 million seedlings in 2001).

With regard to planting and soil conservation, mechanical anti-erosion installations were established on 50,628 ha and biological installations on 4,550 ha of surface, out of which some 10,000 ha are covered by plantings. In addition, $1,500 \mathrm{~km}$ of linear plantings (windbreaks, field borders, travel corridors, etc.) and some 5,000 ha of plantings on restricted areas were accomplished. Agro-forest plantings were established on some 6,570 ha.

Mechanical operations were undertaken to control water hyacinths upstream and downstream on the Niger River, helped improve river navigability, conservation of biological diversity in general and fishery resources in particular.

84 bodies of water were stocked with fish. This was accompanied by planting, extraction and appliance of 10 ha of biological agents, and the start-up of activities to train and equip fishermen and fishmongers. A total of 124 ponds and 31 dams were stocked with fish from 2000 to 2002.

Between 2000 and 2002, some 7,272 km of fire breaks were installed. To safeguard grassland ecosystems, $37,120 \mathrm{~km}$ of fire breaks were inspected and 913 fire rangers trained.

In terms of participatory management of natural forests, the establishment of 24 new rural wood markets was recorded registered and 52 land-use plans developed, in close collaboration between technical services and local residents. The area covered by these landuse plans is 10,000 ha. 
With regard to the definition and implementation of sectoral strategies and policies, a national strategy to resume production and marketing of gum Arabic was developed and validated at a workshop held in November 2002 in Niamey. This meeting brought together all the stakeholders in this issue.

\section{I - 4-2 Agricultural development}

In Niger, there is grain shortage in one of every three years. The capacity of the people to deal with this situation is limited, due to the weak capacities of individual farmers to respond to food emergencies and the weak organizational capacity of rural communities in managing such emergencies. As a consequence, the PRS puts special emphasis on reducing the vulnerability of the rural population by strengthening food security and developing income generating activities (AGR).

With regard to measures to increase food security, notable results have been achieved over the last twelve months, including the completion of 46 mini-dams and 42 irrigation sills as part of the PRSP implementation. The total size of the areas that potentially benefit from these new installations in the form of irrigation is estimated at some 6531.5 ha.

According to harvest forecasts and estimations, grain production in 2002 resulted in a surplus of 315,000 metric tons, while 1,841 villages with shortages were identified. Operations to sell grain at moderate prices conducted in all regions during the bridge period (May to September) have helped improve the food situation in the areas with shortages.

2002 was also marked by the continued preparation of the second general agriculture census. As part of this, two studies were conducted: a study on improvement of the Harvest Forecast and Estimate Survey and a study on the methodology of the Census on horticulture products.

In regard to the development of agricultural industries, actions undertaken involved the production of grain industries and the creation of 8 stores for inputs.

For developing income-generating activities, a credit program for economic interest groups and for rural women financed activities of some 352 groups (2,928 beneficiaries) for an amount of CFAF 92 million.

\section{I - 4-3 Animal resources}

The year was marked by the development and adoption of the framework document for development of the livestock sector on March 12, 2002. This document, which now serves as strategic basis for livestock sector development policy, includes twelve (12) priority programs and the following seven (7) strategic action components:

$\checkmark$ improvement of natural resources and enhancement of grazing zones and spaces;

$\checkmark$ improvement in animal health;

$\checkmark$ improvement in animal productivity (genetically and through feeding/watering);

$\checkmark$ contribution to food security and fighting poverty;

$\checkmark$ support for the organization and professionalization of stakeholders;

$\checkmark$ promotion of domestic and export markets and enhancement of competitiveness; and

$\checkmark$ adaptation of support functions.

The following practical actions were carried out in 2002: 
$\checkmark$ improvement of natural resources management as part of the process of developing the rural code and the land-use plan for grazing land;

$\checkmark$ preparation of the general livestock census, in order to have reliable statistics for the rational use of animal resources;

$\checkmark$ improvement of animal health by the continuation of animal vaccinations and strengthening epidemiological monitoring to control diseases;

$\checkmark$ enhancing production conservation and processing of milk and dairy products by acquiring 1,063 cows and 25 breeders as part of the pilot project for semi-urban dairy farming;

$\checkmark$ establishment of two modular dairy farms in Tahoua and Maradi in the context of a project aimed at strengthening installations in livestock centers; and

$\checkmark$ conducting feasibility studies for (i) a cattle breeding support project in the Zinder region; and (ii) a program in fostering economic activities in the pastoral sector.

\section{I - 4-4 Improvement of the road network and transportation}

The program is designed to expand construction of roads and rural tracks from areas of agricultural production to secondary highways and urban centers, to facilitate food security, commercialization of agro-pastoral production surpluses, increase in rural revenues, enhancement of productivity and access by the poor to socio-economic infrastructures.

As concerns the national highway network, the year 2002 was marked by the rehabilitation of the Niamey-Dosso road and the beginning of rehabilitation work on the section leading from Niamey to the border with Burkina Faso and $36 \mathrm{~km}$ of the Agadez-Zinder road. Another important achievement was the building of unpaved roads (rural tracks).

Feasibility studies for sections of State Highway No. 1 were undertaken, including completion of technical studies for the Guidan-Roumdji section $(96 \mathrm{~km})$ in April 2003, for which actual construction is expected to start in September 2003. As regards the rehabilitation of ZinderGoure portion, the first phase of the feasibility study which relates to the Zinder-Guidimouni road $(63 \mathrm{~km})$ was completed in June 2003. The second phase, which is ongoing, relates to the Guidimouni-Gouré portion $(103 \mathrm{~km})$.

Concerning rural tracks, a total road length of $898 \mathrm{~km}$ is either under construction or almost completed. The financing of construction of rural tracks is provided under ongoing projects and programs. The timely completion of the tracks has been problematic due to cumbersome procurement procedures.

A key achievement in the transport sector in 2002 was the preparation of a national transportation plan. To that effect, a study to establish a strategy for road transport was completed. 
Box 2: Constraints on Highway Maintenance Finance Fund (CAFER)

CAFER was created in 1999 under the aegis of the Ministry responsible for public works. Its objective is financing and maintaining roads. Its resources come essentially from toll road fees and the operation, directly or under license, of the national highway network. CAFER operations face a number of problems. The main constraint on CAFER remains mobilization of adequate resources.

In 2001, the National Treasury released 3.754 billion to CAFER (of which 2.100 billion was budgetary assistance from AFD (the French Development Agency) directly allocated to CAFER) in two tranches (on February 15 and September 25). This made it possible to carry out several projects included in the program approved by the Highway Council, both before and after the rainy season

In 2002, implementation of the program progressed in concordance with funds made availability through transfers from the Treasury to CAFER

The first installment received was allocated to road work in urban areas (more than 900 million including taxes). The remaining installments were allocated on the basis of expressed needs for emergency works required to restore road traffic after damage caused by heavy rains

Of a 4.5 billion program approved by the Highway Council, the National Treasury was able to pay CAFER only 48 percent.

The need for road maintenance is greater after than before the rainy seasons and CAFER is therefore requires adequate funding for restoring the damaged network. At the same time the collection of road tolls by the Chamber or Commerce was limited to 306 million as of November 15, 2002, which represents only 34 percent of the expected amount for 2002. Although CAFER has made strong efforts to collect what it is owed, the Highway Council has instructed CAFER to prepare terms of reference for competition for the concession.

\section{I - 4 - 5 Urban development}

The following strategic orientations were defined in the PRS:

$\checkmark$ planning urban development through the establishment of an adequate institutional framework and the improvement of urban structures;

$\checkmark$ improving living conditions for the poor by improving their habitat through the development of a social housing policy; and

$\checkmark$ improving the urban environment by developing and implementing urban renewal plans.

In order to respond to these strategic orientations, a national urban development strategy is being prepared under the leadership of the Ministry of Urban Planning, Habitat, and Public Property (MU/H/DFP); it will include an action plan and an assistance program for the urban development sector.

A number of studies to develop mechanisms for urban renewal and planning have been completed. In addition, the operation to allocate land parcels in compensation for salary arrears of civil servants was continued in 2002. Under this program, 16,026 parcels were granted for a total cost of CFAF 10,124 billion. 


\section{I - 4-6 Tourism and handicrafts}

A study to define a National Tourism Policy was completed in October 2002, in order to revitalize this sector. At the same time, the construction of new tourist sites has begun, in the context of improvement of accommodations for visitors. New tourist sites were identified in the regions of Tahoua, Tillabéri and Agadez. From June 2002 to June 2003, eight new units were built for a total cost of CFAF 2,492 billion and 16 existing units were refurbished for a total cost of CFAF 3,204 billion, in order to increase existing tourist and hotel capacities.

In the handicraft sector, the institutional framework, the capacities of artisans and their working conditions have been strengthened. Promotional events (leather week, national handicrafts festival, fairs, etc.) were organized to enhance the exports of handicrafts.

Special attention was given to women working in the handicraft sector. Some 80 women were trained in the promotion of women's activities and capacity building of women artisans in rural areas.

In order to improve and develop micro and small enterprises in rural areas, the system of micro-credits for handicraft activities was strengthened.

\section{I - 4- 7 New technologies}

Following the privatization of the Société Nigérienne de Télécommunication (SONITEL), 2002 was marked by finalization of SONITEL's business plan, the launching of Global Satellite Mobile (GSM) telephony operations, the rationalization of the subscriber/customer database and the design of a plan for financing and public contracting the purchase of equipment in order to develop both fixed and mobile networks.

In November 2000, Niger awarded two GSM cellular licenses through an international public bidding process to the two companies TELECEL and CELTEL-Niger. ${ }^{1}$ The latter started operations on October 17, 2001 and had registered some 15,000 subscribers in Niamey and Maradi by late 2002. A third operator, SAHEL COM, which is a SONITEL subsidiary, began its activities on August 1, 2002, and has some 10,000 subscribers.

The rapid development of cellular telephony in Niger has responded to a latent demand, as expressed by the number of subscribers, which has nearly doubled since the sector was deregulated.

Internet services are still provided by SONITEL, which increased its internet access capacity in 2002.

In order to provide better access to information in the rural areas, 28 community radios were installed in the course of 2002.

\section{I $-4-8$ The private sector}

It has been recognized that without a strong and dynamic private sector, it is not possible to achieve sustained growth and ensure profitability of national production.

${ }^{1}$ CELTEL-NIGER is a subsidiary of Mobile Systems International Holding Company, which owns 70 percent of the capital, leaving 30 percent to Soni, S.A., a Nigerien company. 
Private initiative must constitute the basis for revitalizing the economy, especially in the rural sector. At the same time equity necessary for social cohesiveness must be preserved.

Accordingly, promotion of private sector development has a central position in the strategy. In this regard, a study on the challenge of accelerating growth was finalized in July 2002, as part of a private sector assessment.

In fact, the retreat of the government from a number of productive sectors and the elimination of its monopoly should allow the emergence of new players in the economy and a more efficient and competitive market.

However, a short assessment of the situation of the private sector suggests a mixed outcome:

$\checkmark$ A purchasing agency that buys fertilizer on the international market, while at the same time managing donations and selling them $r$ at subsidized prices to groups of producers, has a determining position on the fertilizer market. Sales of subsidized fertilizer limit the possibilities of private suppliers to earn profits and conquer new markets.

$\checkmark$ The withdrawal of the government from seed provision has led to an increase of involvement of private actors only in the context of projects. Volumes of improved seeds produced have declined substantially; and

$\checkmark$ Downstream production, previously exclusively in the government's domain, has only in rare cases been taken over by private operators. In the case of rice, the public processing company (RINI) operates at very low capacity, and only one private processing unit has set up to claim a portion of the market. Industrial processing of peanuts is concentrated in the hands of two operators. There is no processing facility for horticulture products.

Mainly oligopolies consisting of private companies and public operators (the role of which is often poorly defined) dominate the upstream and downstream aspects of agricultural, forest, and livestock production.

The situation in rural banking is quite similar. Since the end of the $1980 \mathrm{~s}$, the rural areas have been practically deprived of any formal credit system as the result of the failure and successive bankruptcies of conventional rural credit systems. Micro credit systems have been established, yet to reach out only a very small part of rural residents and do not provide medium and long term loans.

All these shortcomings reflect the unfavorable investment conditions that are generally attributed to a high degree of uncertainty and lack of market transparency.

Public intervention is therefore justified to create conditions that will motivate businesses to invest, through measures aimed at the promotion of a more stable and transparent economic environment as well as higher yields for products. The SDR therefore seeks to improve pricing policies, choice of public investments, legislative framework and to ensure respect for rules (good governance). 


\section{I - 4 - 9 Employment}

The employment sector has seen a significant evolution in spite of the limited recruitment of employees within the public sector. The Nigerien Agency for the Promotion of Employment (NAPE) and the Ministry of Youth and the Professional Integration of Young People have contributed to the creation of jobs in the public, para-public and private sectors. In this regard, these institutions along with youth and business representative met in Niamey in order to discuss the employment problems facing the youth.

In 2002,670 youth were employed by micro-enterprises in the public health sector in Niamey. Also, a youth corps project involving 500 youth was launched

\section{I - 5 Development of social sectors}

The weakness of social indicators is one of the elements explaining Niger's low position in the Human Development Index ranking of the United Nations. This has led the government to make improved access of the most deprived to education, health care, sanitation and drinking water, to one of the priority components of the PRS.

\section{I-5-1 Education}

\section{I - 5- 1 - 1 Basic education}

The PRS emphasizes the importance of improving education to achieve the objectives of substantially reducing poverty. Access to basic education and literacy has an undeniable impact on improving health, living conditions, and local structures.

The objectives adopted in the PRS for the educational sector were less ambitious than the targets set by the Millennium Development Goals (MDGs), given Niger's backwardness in this area. The objective for primary school enrolment adopted in the PRS is 84 percent in 2015 , compared to 100 percent for international objectives. At the same time, the PRS remains ambitious regarding the access of girls to education because of the importance it has assigned to achieving gender equality by 2005 . Given the new strategic orientations of the educational policy defined in the Ten-Year Education Development Program (PDDE), the objective of an enrolment rate of 84 percent has been revised so that Niger is able to meet the challenge in 2015 with respect to universal access to education.

In 2002, substantial efforts were deployed in building schools and recruiting teachers. Some 1,830 additional classrooms were built and 2,773 volunteer teachers recruited. This brings the total number of basic education volunteer teachers to 10,369 . The following table shows the basic education 1 indicators for 2002. It shows that the achievements in 2002 broadly exceeded the forecasts. 
Table 7: Education sector development indicators

\begin{tabular}{|l|c|c|c|}
\hline \multicolumn{1}{|c|}{ Education } & $\begin{array}{c}\mathbf{2 0 0 1} \\
\text { Baseline }\end{array}$ & $\begin{array}{c}\mathbf{2 0 0 2} \\
\text { Goal }\end{array}$ & $\begin{array}{c}\mathbf{2 0 0 2} \\
\text { Achievement }\end{array}$ \\
\hline Gross primary school enrollment rate & $37.3 \%$ & $40 \%$ & $41.7 \%$ \\
Gross primary school enrollment rate in rural areas & $32 \%$ & $34 \%$ & $38.1 \%$ \\
Gross rate of primary school enrollment for girls & $29.6 \%$ & $32 \%$ & $33.3 \%$ \\
Percentage of girls in primary school & $39.4 \%$ & & $39.8 \%$ \\
Literacy rate & $19.9 \%$ & - & - \\
Primary school completion rate & $23.7 \%$ & $24 \%$ & $25.6 \%$ \\
Rate of access to first year of primary school & $40.1 \%$ & $42.4 \%$ & $49.8 \%$ \\
Rate of survival in primary school & $54 \%$ & $56 \%$ & $57 \%$ \\
& & & \\
\hline
\end{tabular}

Source: Ministry of Basic Education and Literacy.

$$
\text { I - 5- 1-2 Literacy }
$$

Available statistics on literacy do not reveal an accurate picture of the situation. Aware of the weakness in literacy levels, the government launched a vast literacy campaign in 2002, which led to infrastructure development and increase of registered students, among them a large share of women, at literacy centers. 474 literacy centers were open to the public in 2002.

\section{I - 5-1 - 3 Secondary and post-secondary education}

Encouraging results have been observed in the implementation of the PRS. In 2002, a national policy on post-secondary education was developed. Accordingly, actions involving research and the restructuring of Abdou Moumouni University (UAM) were carried out. The UAM's capacity for accepting students was enhanced by building new classrooms and lecture halls.

A program to create University Institutes of Technology (IUT) has been developed and may benefit from support from OPEC funds. In addition, a new curriculum for Arab language teaching was prepared. The African Virtual University was also revived through the set up of a digital campus.

As regards private education, regulatory texts and educational programs were developed. Finally, the Ten-Year Higher and Secondary Education Plan is being elaborated.

\section{I - 5-1-4 Professional and technical education}

Within this framework, the strategy consists of strengthening the capacity of centers for professional and technical education and increase their numbers, in order to permit a maximum of youth, who left the school system, to learn a trade that would help them in participating in the economy. Seven new centers have been created and will assume operations at the start of the new academic year in the regions of Tillaberi, Dosso, Tahoua, Agadez, Diffa and a supplementary center in Niamey.

In addition, under the Special program of the President, 1000 youth are trained in the National Service for Participation in areas such as agro-forestry-pastoral, carpentry, masonry, etc. 


\section{I - 5 - 2 Health}

In May 2002, the Strategic Orientations for Health Sector Development for 2001-2011 were adopted. They contain the following priority components: disease prevention through public information programs, improved community hygiene, an increased vaccination coverage rate, the design and implementation of a plan for fighting epidemics and the reorientation of public investments to achieve better health coverage for the country.

Under the same strategic plan, special attention will be given to reproductive health, including women and children's health, nutrition, family planning and the fight against HIV/AIDS as well as sexually transmitted infections. Moreover, the fight against communicable diseases, especially malaria, HIV/AIDS, and tuberculosis, will remain a priority.

Finally, to promote equity, the poorest will continue to benefit from national solidarity through shared health costs. The Health Sector Development Plans for the Districts are implemented to ensure better decentralization of health care provision.

The following table summarizes the goals and achievements in 2002 in reference to 2001 .

Table 8: Health sector development indicators

\begin{tabular}{|l|c|c|c|}
\hline \multicolumn{1}{|c|}{ Health } & 2001 baseline & $\begin{array}{c}\mathbf{2 0 0 2} \\
\text { Goals }\end{array}$ & $\begin{array}{c}\mathbf{2 0 0 2} \\
\text { Achievements }\end{array}$ \\
\hline Rate of health coverage (0-5 km ) & $47.6 \%$ & $47.6 \%$ & $56.4 \%$ \\
Rate of measles immunization & $52.75 \%$ & - & $48 \%$ \\
Rate of malnutrition children < 5 years & $39.6 \%$ & - & - \\
Rate of DTCP 3 immunization & $31 \%$ & $40 \%$ & $22 \%$ \\
Rate of tetanus immunization of pregnant women & $41 \%$ & $45 \%$ & $36 \%$ \\
Rate of BCG immunization & $50 \%$ & $50 \%$ & $46 \%$ \\
Rate of AIDS prevalence & $1.4 \%$ & $0.70 \%$ & $0.87 \%$ \\
\hline
\end{tabular}

Source: Ministry of Public Health and Combating Endemic Disease.

The different indicators reveal a concerning health situation, characterized by a low level of achievements compared to objectives. This situation reflects the weak monitoring capacity in the health sector.

With regard to the HIV/AIDS, a national sero-prevalence survey was conducted among different groups between May and August 2002. The results of this survey show a prevalence rate of 0.87 percent.

Rehabilitation and construction of health infrastructure was carried out supported by the Health II Project, along with health units built by the Special Program. Furthermore, a number of district hospitals were rehabilitated and a large number of many health centers equipped. 
Table 9: Existing or almost completed infrastructures as part of the

Health II Project from 2002 to 2003

(In CFAF billion)

\begin{tabular}{|l|c|r|}
\hline \multicolumn{1}{|c|}{ Description } & Number & Cost \\
\hline $\begin{array}{l}\text { Rehabilitation and expansion of Integrated Health Centers } \\
\text { (CSI) }\end{array}$ & 43 & $2,219.3$ \\
\hline Rehabilitation and expansion of district hospitals (HD) & 4 & $1,849.0$ \\
\hline $\begin{array}{l}\text { Rehabilitation and expansion of the Regional Hospital Center } \\
\text { (CHR) in Diffa }\end{array}$ & 1 & 977.3 \\
\hline Improvement of the HD of the Population Project & 9 & 183.9 \\
\hline Rehabilitation of CNAT & 1 & 27.8 \\
\hline CST built and received & 10 & 558.2 \\
\hline CSI under construction $^{2}$ & 52 & $2,068.3$ \\
\hline Drinking water supply for the CSIs & 86 & 993.7 \\
\hline Total amount & & $8,877.5$ \\
\hline
\end{tabular}

Source: Health II Project.

With respect to the DTCP 3 immunization rate, its low level in 2002 was caused by a delay in the delivery of vaccines that caused interruption of antigens in a number of health centers. This problem was reinforced by the inadequate staffing in health care facilities. It was envisaged to recruit 536 contractual health workers of all categories in 2002 . This was aimed at improve staffing of the basic health centers, in order to ensure quality standards in service provision and consolidate past achievements. Unfortunately, only 483 agents were recruited and only 270 of these have actually their new assignments.

The pilot analysis of the impact of on health expenditures on poverty has not been conducted. Such a study is required for an accurate assessment of factors determining health care demand. In addition, dysfunction of the services responsible for gathering and processing statistical data is evident, especially in terms of delays faced in getting information from the health districts to the national level. It should also be noted that the available statistics do not allow classifying indicators by gender. This could be a focus for improving health data.

Finally, it should be noted that the trends for certain indicators cannot be assessed solely by surveys. This is a reason for problems in tracking them on an annually basis.

\section{I-5-3 Demographic constraints}

According to the provisional results of the third general population and habitat census, published in May 2003, the population of Niger is growing at a rate of 3.1 percent per year. This rate of demographic growth results from high fertility. The results of the study of the population of Niger finalized in June 2003 show that population issues could constitute a real obstacle to the implementation of the PRS and the achievement of the MDGs. According to the results of this study, if current demographic trends continue, Niger could have 53 million inhabitants in 2050 and have the second largest population in West Africa after Nigeria.

\footnotetext{
${ }^{2}$ This involves the carrying out of 32 installations of mini "AEP", 42 drillings and 12 wells.
} 
These demographic constraints alone would make the objectives for socio-economic development and anti-poverty goals virtually unachievable. Therefore, if no steps are taken to contain demographic growth, it would become impossible to address the needs for food security, universal enrollment in primary schools, health coverage, vaccination and water resources and the goals set for poverty reduction risk becoming unrealistic.

\section{I - 6 Good governance, decentralization and strengthening capacities}

\section{I - 6 - 1 Good governance}

As a strategic focus, this cross-sectoral component of the PRS should make it possible to avoid repeating the problems of the past, especially in the implementation of the development programs. It seeks to remedy the defects and institutional shortcomings that have affected the functioning of the government and facilitate reforms that will build the foundations of good governance in the political, administrative, economic, and local realm.

With respect to political governance, national policies are guided by the constitution, the charters of the political parties, and policy framework adopted by the government. These policies are based on the main principles of a pluralist democracy, rule of law, consolidation of peace and political stability, promotion of human rights, independent judiciary, and a republican army.

In terms of the actions already undertaken, particularly worth noting is the preparation of a Judicial Reforms Support Program (PARJ), which is being established with the support of Niger's development partners. This program is especially important, given the close links between poverty and the lack of access to justice. Other actions have also been conducted, such as awareness programs on the principles of political governance, follow-up on the recommendations of the symposium on "Army and Democracy", the reinforcement of human rights organizations and the pilot program on collecting Illicit Small Caliber Arms (PPCAIPC).

Concerning communal enterprises in Diffa, Zinder, Maradi, and Tillabéri, financial and legal mechanisms have been developed. A study of how best to use these tools within the context of the PRS implementation is underway.

In addition, a national strategy for conflict prevention and management was validated through a meetings held in Agadez in April 2003, attended by the Prime Minister, members of the government, development partners as well as representatives of civil society, Parliament, political parties and unions. This innovative approach (a first in the sub-region) will doubtless give Niger an effective instrument for social dialogue, creating the basis for good political governance.

\section{I - 6 - 2 Decentralization}

The adopted decentralization scheme is a compromise between the comprehensive scheme that envisaged 774 communities and a more limited proposal. This scheme is based on cantons and "groupements", which are the traditional structures that currently constitute the basis for the administrative and territorial organization of the country. 


\section{I - 6-2 - 1 Current status of decentralization}

2002 was marked by the finalization and adoption of various legal texts. There is now a corpus of basic legal texts on decentralization that provide a clear idea of how the future territorial collectivities ("collectivités territoriales") will operate:

$\checkmark$ Law 2002-12 of June 11, 2002, defines the fundamental principles of the free administration of regions, departments, and communes, and their respective powers and resources;

$\checkmark$ Law 2002-13 of June 11, 2002, transfers powers to the regions, departments, and communes;

$\checkmark$ Law 2002-17 of June 11, 2002, defines the financial system for the regions, departments and communes; and

$\checkmark$ Laws 2002-14, 2002-15 and 2002-16 concern the creation respectively of the communes, the Niamey urban community and the Tahoua, Maradi and Zinder urban communities.

After these laws were enacted, actions concentrated on:

$\checkmark$ broad dissemination of the decentralization legal texts;

$\checkmark$ appropriate training of involved actors, especially lower level officials; and

$\checkmark$ search for the best conditions for the installation of the future communes by estimating needs and putting in place administrative infrastructures and a minimum level of equipment.

The legal provisions regarding the functioning of the territorial communities follow standard structures, with an executive (whose head is a President of the Regional Council, a President of the Departmental Council or a Mayor), a legislative body that acts as checks and balance and administrative services. While these local communities are granted a general competence clause, which is traditional in such cases, they also have specific powers listed by Law 200212 and clarified by Law 2002-13, on the powers transferred by the state to the territorial communities.

The laws enacted in June 2002 provide proper institutional arrangements for the functioning of the three decentralized entities (Regions, Departments and Communes), and ensure consistency in the division of roles between these different entities., especially with regard to their powers and resources. In fact, the transfer of powers from the government to local communities will be gradual, and at first, the communes will be able to operate essentially on the basis of the principle of the "general competence clause" contained in sections 97 and 98 of Law 2002-12, which allows the communes to intervene in all areas of local life, and in particular those specified in the cited sections.

The effective exercise of these powers by the local communities will result at the local level in a substantial change in the role of the government, whose new definition will be specified in greater detail in the "Deconcentration Charter", which is currently being drafted. The immediately enforceable character of the decisions made by the local communities and the fact that the representative of the State at different levels of government has the option of referring illegal decisions to the administrative judge stand out as original provisions compared to other decentralization schemes in the sub-region. 
Following the strategic decision of government of the $5^{\text {th }}$ Republic aims at devolving a maximum amount of political authority to the level of the communities, Niger will create 213 rural communes, 52 urban communes and 4 urban communities, covering all of the country's territory. This new structure is the fruit of a long process that was both participatory and iterative. On a trial basis, 20 pre-communes were created and 4 more are being set up in the Diffa, Maradi, and Zinder regions.

The successful implementation of the decentralization process depends on the reinforcement of the capacities of the stakeholders through training and on making available qualified personnel at the local level.

\section{I - 6- 2 - 2 Financial implications of decentralization}

Establishing communes, especially rural communes, will require substantial human, financial and material resources. To ensure that the decentralization process is successful, the allocation of resources must happen in time to allow the installation of executive bodies of the communes within the regulatory period of fifteen (15) days after the final proclamation of the results of local elections. . The High Commissioner for Administrative Reform and Decentralization has estimated the overall costs of the installation of the 265 future communes as shown in the table below:

Table 10: Breakdown of costs as a function of financing needs

\begin{tabular}{|l|r|}
\hline \multicolumn{1}{|c|}{ Financing needs } & \multicolumn{1}{c|}{ Total costs } \\
\hline Property infrastructures & $3,223,972,892 \mathrm{~F}$ \\
\hline Furniture & $827,065,000 \mathrm{~F}$ \\
\hline Training actors involved in decentralization & $1,852,500,000 \mathrm{~F}$ \\
\hline Information and awareness campaigns & $152,537,000 \mathrm{~F}$ \\
\hline Reconciling of debts & $1,964,602,916 \mathrm{~F}$ \\
\hline Computer equipment & $397,500,000 \mathrm{~F}$ \\
\hline Creation of two funds to benefit the Territorial Communities & $10,400,000,000 \mathrm{~F}$ \\
\hline Support for cvaluation of the decentralization program & $442,000,000 \mathrm{~F}$ \\
\hline \multicolumn{1}{|c|}{ General total } & $19,620,177,808 \mathrm{~F}$ \\
\hline
\end{tabular}

Source: High Commission for Administrative Reform and Decentralization.

Reflections will need to be undertaken on the capacities of the new communities to generate own resources that will assure their functioning.

\section{I - 6-3 Strengthening capacities}

Capacity building occupies an important place in the implementation of the PRS because it will requires changes and improvements in the management of the administration, its functioning and its relations with other development actors. The dialogue between the government and the various stakeholders involved in the implementation of the PRS will be strengthened with a view to create a climate of mutual confidence among the parties. 
The creation in October 2001 of the Development Analysis and Forecasting Cell ${ }^{3}$ (CAPED), which reports to the Prime Minister's Office constitutes an important step towards strengthening capacities.

The priority actions selected in the PRS include strengthening capacities, installing a system for monitoring and evaluation, and putting in place a medium term expenditure framework in order to institutionalize actions conducted as part of the implementation of the PRS.

Actors involved in government financial operations at the national and regional level have been trained on the new budget analysis instruments, in particular the chart of accounts and budget structure.

\section{II - Monitoring and knowledge of poverty}

\section{II - 1 Monitoring mechanism}

The current mechanism for monitoring poverty has shortcomings. For several years, Niger developed and implemented numerous economic reform and development programs, most of them aimed at improving the living conditions of its people. The results, effects or impacts of these programs could not be evaluated appropriately because of the great weakness of the various evaluation systems, which are divided among sectoral departments, regions and between within the quasi public and private structures.

This situation is reinforced by a lack of interest in statistical information within government. Only certain external users ascribe importance to the available statistical data. In sum, the national statistical system is characterized by weak institutional, methodological capacity and insufficient data collection and analysis. Added to these major shortcomings are the unreliability of the information generated and the lack of coordination, resulting in an incorrect appreciation of the situation and great diversity of data sources.

To remedy this problem, a note on monitoring and evaluation was prepared in 2002 in collaboration with all stakeholders (DSCN, DSEP, DEP of the technical ministries, civil society, and the SP/DSRP). This note provides main strategic guidance and confirms the commitment of the authorities to devise an efficient system for monitoring and evaluation that will be used for the implementation of the PRS.

The identification of data needs has been the most important prerequisite to creating and implementing an integrated information, monitoring and evaluation system for the PRS. Full knowledge of real and relevant data needs, in function of the objectives pursued, can serve as the foundation of this system.

Appropriate monitoring indicators have been according to products, effects and impact of the poverty reduction strategy and the MDGs. It takes into consideration the dimensions of poverty in Niger and its great diversity.

The indicators defined in a way that allows for an understanding of the factors behind monetary poverty, quality of life, socio-economic and economic potentialities and governance and responsibility. Indicators linked to gender and HIV/AIDS are also used.

\footnotetext{
${ }^{3}$ The authority, organization and functioning of CAPED are defined by Order 0010/PM of February 21, 2002.
} 
The core of selected indicators can be categorized:

$\checkmark$ input indicators for monitoring the level of resources assigned to services and programs. This type of monitoring essentially focuses on control and financial analysis such as audits and public expenditure reviews. It also allows monitoring of available human and material resources. The main sources of information for this type of indicators are administrative records and project and program execution reports from technical ministries and the financial services of the Ministry of Economy and Finance (General Budget Directorate, Investment Financing Directorate);

$\checkmark$ Output indicators for monitoring the provision of services designed to reduce poverty (such as the construction of schools, health centers, farm education services, water resource infrastructures, etc.). These indicators enable the assessment of execution of investments conducted as part of programs and projects aimed at reducing poverty. The data required for this purpose essentially comes from the administrative records of the programs/projects and internal statistics from the Ministries of Trusteeship and Finance and Economy;

$\checkmark$ Indicators for measuring impact on beneficiaries for monitoring access of people to investments undertaken for poverty reduction programs and projects, the quality of the services offered through these programs and projects and the impact of investments on living conditions. These indicators are used to evaluate the effects of the poverty reduction programs/projects; and

$\checkmark$ Outcome indicators used for evaluating the general effect of measures on well-being and poverty levels.

\section{II - 2 Production and dissemination of data}

Specific data collected through consumption budget surveys, participatory evaluations of poverty and household panel studies are required to monitor and evaluate the impact on beneficiaries..

In order to obtain more updated data on poverty, the Statistics and National Accounts Directorate (DSCN) started the preparations for a National Household Consumption Survey (ENBC). A steering committee for this survey has been in place since June 2002. The survey preparation has benefited from support from the World Bank in the design of the survey methodology and the development of a work schedule covering 12 months. The overall cost of the operation is estimated at CFAF 1.8 billion, for which 180 million was included in the 2002 budget to finance preparatory activities.

However, important problems have arisen in the implementation of the this important survey:

$\checkmark$ delays incurred in the processing and publication of results of the $3^{\text {rd }}$ general census which hamper the sampling work; and

$\checkmark$ financial constraints that affect the survey execution schedule.

As concern data production, the publication in May 2003 of the preliminary results of the Third Population and Habitat Census of May 2001, the publication of government accounts and the regular publication of the consumer price index should be note. 
Finally, as part of the preparation of the General Agriculture and Livestock Census of(RGA/E), pilot surveys were launched during May 2003. These surveys will make it possible to adopt appropriate methodology for this census, which is scheduled to take place during the 2004 campaign.

\section{II - 3 Knowledge of poverty}

A qualitative study was conducted in all regions of the country between December 2001 and January 2002. A survey was conducted at a total of 49 sites, of which 19 were urban or semiurban. Data was collected for a number of topics of interest, using structured interviews and participatory survey techniques. In total, 3,950 people were interviewed, including local players, administrative authorities, women's leaders, etc. Young people predominated in the sample of respondents of the population, at 67.2 percent, followed by adults at 28.4 percent and elderly people at 3 percent. With respect to gender, 48.52 percent of respondents were women and 51.48 percent are men. In terms of where they live, 54.5 percent of those interviewed were from rural and 47.5 percent from urban environments. The interviews covered the country's main ethnic groups. The discussions were free and open and dealt essentially with living conditions, perceptions of poverty, the relationship between poverty and policy interventions and the needs of communities in terms of different services.

This study confirmed the diagnosis elaborated as part of the preparation of the full PRSP. Nevertheless, it provides some interesting conclusions on the knowledge of poverty in urban settings. The results of this study were published in June 2002.

\section{III - Future prospects}

\section{III - 1 Macroeconomic framework}

In 2003, the government intends to continue the implementation of the reforms aimed at safeguarding a stable macroeconomic framework, contain inflation and increase the efficiency of tax administrations in mobilizing resources.

In particular, the government will maintain a strict fiscal policy, allowing overall demand to be contained at a level compatible with the resources available and the regional goals adopted as part of WAEMU. It will especially respect commitments made as part of the program supported by the poverty reduction and growth facility from the IMF and put in place conditions for respecting the WAEMU convergence criteria in the medium term. For this purpose, the Government will focus its efforts on the control and rationalization of public expenditures and on ensuring sustainability of the public debt while carrying out actions to improve the effectiveness of revenue collection.

To ensure an optimal allocation of resources, the government will begin the modernization of the budget preparation and programming by determining budget allocations in function of economic and financial criteria, in accordance with the medium-term expenditure framework (MTEF). The MTEF will determine budget envelopes by sector, consistent with the macroeconomic framework.

Regarding public debt, the government is committed to define a viable debt policy, in the medium and long term in line with the conclusion of a study on external debt sustainability which is scheduled for 2003. The search for new external financing will emphasize the 
mobilization of non-reimbursable budget assistance, HIPC resources and concessional loans. An effort will also be made to create the conditions suitable for the resumption of normal financial relations with all of Niger's creditors, as well as to achieve the participation of a maximum number of partners in the HIPC initiative.

Regarding internal debt, the authorities will continue:

$\checkmark$ to implement the policy of reducing internal arrears as part of an appropriate strategy; and

$\checkmark$ the non-accumulation of new internal arrears, through the strict application of the rules of budget orthodoxy.

\section{III - 2 Sectoral policies}

\section{III - 2 - 1 Education sector}

As part of its strategy for fighting poverty, Niger has adopted a PDDE 2003-13. The PDDE aims at significantly raising the level of education in Niger in order to create and consolidate the foundations of harmonious and sustainable development.

To achieve the objectives set by the PDDE, key strategies have been designed for expanding and improving the quality and relevance of education. A number of cross-sectoral strategies have also been defined.

With regard to expansion, the Government commits to the efficient allocation of government resources to the education sector, in particular the basic education sub-sector. Accordingly, the government will devote:

$\checkmark$ each year, at least 4 percent of the GDP to education in general;

$\checkmark 40$ percent of the resources released by the reduction of debt under the HIPC initiative to promote universal primary school enrolment; and

$\checkmark$ at least 50 percent of the education budget to primary education.

Needs that do not appear explicitly in the financial programming of the PRS, such as preschool, curriculum development and institutional support will also be taken into account. In this context, the opportunities offered by admission of Niger to the FAST-TRACK Initiative will be exploited.

\section{III $-2-2$ Health sector}

Concerning the health sector, "the Strategic Orientations of Health Development for 200111 " will serve as a framework for a multi-year budget in conformity with the macroeconomic framework of the PRS.

The overall objective of these orientations is to improve health conditions for the entire population by the year 2011. This goal will be reached by accomplishing the following intermediate objectives:

Bringing health centers closer to the population by decentralizing health services through the establishment of health districts and reinforced reference hospitals; 
$\checkmark$ Increasing health coverage from 47.6 percent to 80 percent by the year 2011 ; and

$\checkmark$ Improving reproductive health by focusing on women's, children's, and teenagers' health.

\section{III - $2-3$ Water policy}

The implementation of the national water and sanitation policy requires the improvement in the coverage of the water needs of the people. It is expected that by 2005 there will be a significant raise in the rate of coverage of water needs, due to the large number of ongoing and recently initiated projects, most of which will complete the field work between 2003 to 2005. Various project proposals are currently being negotiated and might be undertaken in the same period.

\section{Box 3. Prospects for Achieving the Millennial Development Goals}

Achievement of the Millennial Goals is a major challenge for the PRS. In this context, the following actions are intended to be undertaken. .

For reducing monetary poverty and combating hunger: diversify the economy, increase employment and revenues for the poor, especially women, and assure food security.

For education; increase the allocations of government and donor resources, in accordance with the HIPC initiative, expand and strengthen school infrastructure, involve residents in school management and cost sharing, decentralize the educational system and create awareness about the importance of schooling.

For promotion of gender equality: eliminate gender disparities through a increased school attendance by girls, a political initiative in favor of women and girls and better access for women to all categories of jobs and credits.

For health: reduce mortality of children under 5, improve maternal health and access to health services in general and finally fight HIV-AIDS and important diseases as malaria.

For sustainable development: this requires preserving natural resources, offering drinking water in sufficient quantity and quality to the entire population, particularly in rural zones but also to allow access to decent housing.

For implementation of a development partnership: mobilize development assistance and orient it toward the social sectors while ensuring debt sustainability. The prospects for achieving the MDGs in Niger will be evaluated on the basis of a set of indicators that are the most relevant for Niger.

Source: Prospects for Achieving Millennial Development Goals in Niger.

\section{III - 3 Capacity building}

The proposed measures in the areas of public finances, budget process and program management will require a serious capacity building effort, which would have to cover all the steps in the programming cycle, from program formulation to negotiation with partners, mobilization of funds, internal and external controls and monitoring and evaluation. An 
extension of this effort to the structures of the National Statistical System would be critical to the analysis and monitoring of human development indicators and strategy. The needs for training and repetition courses are enormous. The use of on the job training methods would allow the transfer of external expertise as part of the daily work of the services; technical assistance should be focused on structures for permanent use.

Concerning the creation of a climate of trust, a program for awareness and training aimed at orienting government agents towards service-oriented public sector management and constructive relations with the stakeholders in the field. Workshops will be organized to associate the representatives of the private sector and civil society in the review of the action programs of the PRS. A program to reinforce capacities will be instituted to introduce the participatory process in implementation, monitoring and evaluation of the PRS.

Efforts to reinforce capacities of stakeholders will be continued in accordance with various sectoral programs that have been developed. Special attention will be paid to the national system for production and management of statistical data and the MTEF, in line with the new strategic focus of government policy and the revitalization of the public administration. Besides the necessary financial assistance to acquire equipment and the operation of structures, technical support could be oriented toward:

$\checkmark$ reinforcement of human resources through the organization of sessions or training workshops for managers in the administration and civil society representatives;

$\checkmark$ the design of data gathering, processing, analysis and dissemination tools;

$\checkmark$ identification of indicators that are relevant and respond to the expectations of the main partners;

$\checkmark$ design of a system appropriate for monitoring and evaluation of policies; and

$\checkmark$ support for implementation and the monitoring and evaluating of the two programs initiated by the Ministry of Public Service and Labor.

\section{III - 4 Employment}

In this area, a note for the preparation of a national program to increase involvement of the youth in the economy was validated in August, 2003 in Tahoua.

Within this framework a program for the youth will be prepared that will include the creation of a system of savings and credit. This program will lay the foundations for a national policy on the integration of the youth of Niger.

Besides, a national employment policy is in the process of being prepared. The terms of reference for a study on employment and poverty have been finalized and the request for a consultancy is being examined by the Ministry of Public Service and Labor and the International Labor Organization (ILO). This policy will lead to the formulation of Niger's strategy in the area of employment. 


\section{Box 4: Development Analysis and Forecasting Cell}

Created in the Office of the Prime Minister, the Development Analysis and Forecasting Cell (CAPED), has the of assisting the government in the analysis of development policies and management, through senior specialized officials. CAPED seeks to improve the capacity of the government to play its strategic role in guiding the economy. For this purpose it will develop the necessary skills in all government structures and agencies for political analysis planning and management of the economy.

The objectives of CAPED are:

- promoting a culture of policy analysis and a planning among political decision-makers (government and National Assembly), civil society and the private sector;

- $\quad$ assisting the government in the design and evaluation of policies and strategies;

- organizing training in political analysis and information on the economy through the consolidation of databases and the conduct of studies and surveys;

- assisting in the constitution of a network of experts in policy analysis and forecasting.

The main activities of CAPED will support the design and formulation of Niger's development policies through strategic analyses, training, publications, roundtables, workshops and networking activities.

CAPED is designed to be a center of excellence with financial and administrative autonomy. Its intervention strategy will help create more coherence and synergy in addressing the country's capacity-building needs. This seeks to avoid the duplication of actions undertaken in this field.

\section{III - 5 Monitoring and evaluation}

The establishment of a statistical information management and monitoring and evaluation system for poverty reduction reveals several constraints. Therefore it is necessary to put in place a logical framework for the PRS, which would contain objectively verifiable indicators. For creating the logical framework of the PRS, a task force was created. This task force produced an initial document, which was submitted to a validation workshop in June 2003.

\section{III - 6 Risks}

In spite of the government's commitment, which is reflected in the results obtained in the first year of the implementation of the PRS and the good prospects for the future, the progress towards accomplishing certain objectives of the strategy may suffer from exogenous shocks. The main potential shocks are irregularity of rainfall, political instability in the sub-region, slowness of government processes and insufficient capacity (technical, material and financial) for the effective implementation of the planned activities.

Politically, Niger has returned to the path of stability. This situation has been reinforced by the signing of peace agreements between the government and the armed rebels, which culminated in a "flame of peace" ceremony. The political stabilization will be further strengthened through the successful holding of local elections, which would also confirm the process of decentralization. Achieving progress in the implementation of the decentralization process is a key challenge for the government of the $5^{\text {th }}$ Republic.

Execution of the capacity building program will be instrumental in minimizing some of these risks. The economic risks are linked to the vulnerability of Niger to unpredictable climatic conditions, and, in the short term, exogenous shocks, in particular the Côte d'Ivoire crisis. The lack of progress in the realization of a household consumption survey would hamper knowledge and the monitoring of poverty, which in turn would negatively affect the process of refining the Poverty Reduction Strategy. 
For monitoring and evaluation of the PRS, the weaknesses of the national statistical system could lead to inaccuracies in the analysis of indicators. This risk is low in areas like public finances and education, where important reforms have been accomplished. However, the continuing problems affecting data collection and analysis in the health sector are an important factor in the dysfunction of the system. In fact, one of the major challenges is to introduce a National Statistical Institute, in place of the Directorate of Statistics and National Accounts, in order to appropriately respond to national data needs for monitoring poverty indicators. 


\section{Conclusion}

This report, which presents the progress in implementing the PRS, notes that major progress has been achieved in the management of public finances, health, road infrastructure, rural development and the implementation of the President of the Republic's Special Program. Moreover, the internalization campaigns consolidated the results achieved through the participatory process initiated in the context of the PRS.

The Forum on the PRS on June 7 and 8, 2003 in Niamey has made it possible to reinforce the political dialogue between Niger and its development partners, who agreed to make the SRP the framework for their actions. The Forum also led to the establishment of a basis for donor harmonization of their programs and projects and coordination of their assistance in Niger.

However, the implementation of the strategy has been constrained by unforeseeable events, such as the irregularity and insufficiency of the external financial resources, the constraints associated with the hostile environment, the strong demand pressure for equipment and basic social infrastructures due to a rapid demographic growth, the low personal incomes, various social problems and exogenous shocks resulting from the crisis in Côte d'Ivoire.

Some of the constraints mentioned above have had direct effects on the follow-up of programs, or reversed positive results achieved in some sectors. This applies to agriculture, where in spite of a grain production surplus of 315,000 metric tons, the food security situation remained one of concern in some regions, leading the government to resume sales of grain at moderate prices.

Performance in other sectors, such as health, were mixed, because of problems associated with the mobilization of human resources. Likewise, improvement of knowledge of poverty was affected by the failure to conduct the household consumption survey.

In general, the first year of PRS implementation was very satisfactory. For the remainder of the program, progress will be consolidated and problems encountered during this first year will be addressed. 
ANNEXES 


\section{Annex 1: Financial Operations of the Central Government (in billions of CFA Francs)}

\begin{tabular}{|l|r|r|r|r|}
\hline & \multicolumn{1}{|c|}{$\mathbf{2 0 0 0}$} & \multicolumn{1}{|c|}{$\mathbf{2 0 0 1}$} & $\begin{array}{c}\mathbf{2 0 0 2} \\
\text { estimate }\end{array}$ & $\begin{array}{c}\text { 2003 } \\
\text { program }\end{array}$ \\
\hline Total revenue & $\mathbf{1 1 0 . 1}$ & $\mathbf{1 3 2 . 8}$ & $\mathbf{1 6 0 . 9}$ & $\mathbf{1 6 7 . 8}$ \\
\hline Tax revenue & 102.8 & 125.5 & 144.6 & 158.5 \\
\hline Taxes on international trade & 58.5 & 64.8 & 82.9 & 81.2 \\
\hline Taxes on goods and services & 20.6 & 30.9 & 30.6 & 40.2 \\
\hline Income taxes on revenue and profits & 18.0 & 22.6 & 23.2 & 27.0 \\
\hline Other tax revenue & 5.7 & 7.2 & 7.9 & 10.1 \\
\hline Nontax revenues & 3.8 & 4.1 & 3.8 & 2.3 \\
\hline Annexed budgets/Special accounts. & 3.5 & 3.2 & 4.1 & 4.0 \\
\hline Settlement of reciprocal debt & 0.0 & 0.0 & 8.4 & 3.0 \\
\hline
\end{tabular}

\begin{tabular}{|c|c|c|c|c|}
\hline Expenditure & 214.3 & 245.6 & 278.1 & 303.9 \\
\hline Total current expenditure & 143.8 & 157.4 & 161.8 & 163.3 \\
\hline Budgetary expenditure & 138.5 & 147.1 & 153.7 & 154.8 \\
\hline Wages and salaries & 51.8 & 50.4 & 55.3 & 57.3 \\
\hline Goods and services & 39.9 & 44.2 & 48.7 & 44.7 \\
\hline Subsidies and transfers & 24.0 & 28.1 & 30.3 & 41.0 \\
\hline Interest scheduled & 21.6 & 25.4 & 22.6 & 17.5 \\
\hline External debt & 19.6 & 24.1 & 21.2 & 16.1 \\
\hline \multirow[t]{2}{*}{ Domestic debt } & 2.0 & 1.3 & 1.5 & 1.4 \\
\hline & 5.3 & 10.3 & 8.1 & 8.5 \\
\hline Capital expenditure and net lending & 70.5 & 88.1 & 116.3 & 140.5 \\
\hline Capital expenditures & 73.6 & 89.0 & 116.5 & 140.5 \\
\hline Domestically financed & 8.1 & 25.1 & 27.2 & 35.5 \\
\hline Externally financed & 65.5 & 63.9 & 89.4 & 105.1 \\
\hline of which: HIPC resources & 0.0 & 7.9 & 9.8 & 16.5 \\
\hline Net lending & -3.1 & -0.8 & -0.2 & 0.0 \\
\hline Overall Balance (commitment basis) & -96.9 & -105.6 & -98.5 & -131.3 \\
\hline Basic balance & -49.8 & -57.0 & -44.4 & -17.5 \\
\hline $\begin{array}{l}\text { Change in payment arrears (reduction } \\
- \text { ) }\end{array}$ & -112.0 & -17.0 & -35.5 & -25.0 \\
\hline Internal arrears & 3.6 & -17.0 & -35.5 & -25.0 \\
\hline External arrears & -115.6 & 0.0 & 0.0 & 0.0 \\
\hline $\begin{array}{l}\text { Overall Balance (cash/disbursement } \\
\text { basis) }\end{array}$ & -208.8 & -122.7 & -136.5 & -156.3 \\
\hline
\end{tabular}

Source: Ministry of Finance and Economy. 
Annex 2: Selected Economic Indicators

\begin{tabular}{|c|c|c|c|c|}
\hline & 2000 & 2001 & $\begin{array}{c}2002 \\
\text { Estimate }\end{array}$ & $\begin{array}{l}2003 \\
\text { Program }\end{array}$ \\
\hline Nominal GDP & $1,280.4$ & $1,426.0$ & $1,512.8$ & $1,586.4$ \\
\hline Growth rate (ADP at constant price) & $-1.4 \%$ & $7.1 \%$ & $3.0 \%$ & $4.0 \%$ \\
\hline Inflation (end of period) & $4.7 \%$ & $3.2 \%$ & $0.6 \%$ & $0.4 \%$ \\
\hline Public consumption & 167.0 & 176.6 & 185.1 & 186.0 \\
\hline Investment rate & 11.4 & 12.1 & 14.2 & 15.8 \\
\hline Saving rate & 3.5 & 4.4 & 4.0 & 5.1 \\
\hline $\begin{array}{l}\text { Debt - service to export ratio (before } \\
\text { debt relief) }\end{array}$ & $24.7 \%$ & $27.5 \%$ & $28.0 \%$ & $22.1 \%$ \\
\hline $\begin{array}{l}\text { Debt - service to revenue ratio (before } \\
\text { fiscal relief }\end{array}$ & $51.1 \%$ & $50.0 \%$ & $43.7 \%$ & $36.1 \%$ \\
\hline Total revenue /GDP & $8.6 \%$ & $9.3 \%$ & $10.6 \%$ & $10.6 \%$ \\
\hline Tax revenue /GDP & $8.0 \%$ & $8.8 \%$ & $9.6 \%$ & $10.0 \%$ \\
\hline Total expenditure /GDP & $16.7 \%$ & $17.2 \%$ & $18.4 \%$ & $19.2 \%$ \\
\hline Budgetary current expen diture & $11.2 \%$ & $11.0 \%$ & $10.7 \%$ & $10.5 \%$ \\
\hline Capital expenditures / GDP & $5.7 \%$ & $6.2 \%$ & $7.7 \%$ & $8.7 \%$ \\
\hline Wages/fiscal revenue & $50.4 \%$ & $40.1 \%$ & $38.3 \%$ & $36.2 \%$ \\
\hline $\begin{array}{l}\text { Current account balance BOP (including } \\
\text { grants) }\end{array}$ & -79.1 & -67.9 & -108.4 & -138.9 \\
\hline $\begin{array}{l}\text { Current account balance BOP } \\
\text { (excluding grants) }\end{array}$ & -101.3 & -93.6 & -126.9 & -138.9 \\
\hline $\begin{array}{l}\text { Current account balance BOP (including } \\
\text { grants)/GDP }\end{array}$ & $-6.2 \%$ & $-4.8 \%$ & $-7.2 \%$ & $-8.8 \%$ \\
\hline $\begin{array}{l}\text { Current account balance BOP } \\
\text { (excluding grants)/GDP }\end{array}$ & $-7.9 \%$ & $-6.6 \%$ & $-8.4 \%$ & $-8.8 \%$ \\
\hline
\end{tabular}

Source: TOFE/DFR Ministry of Finance and Economy. 


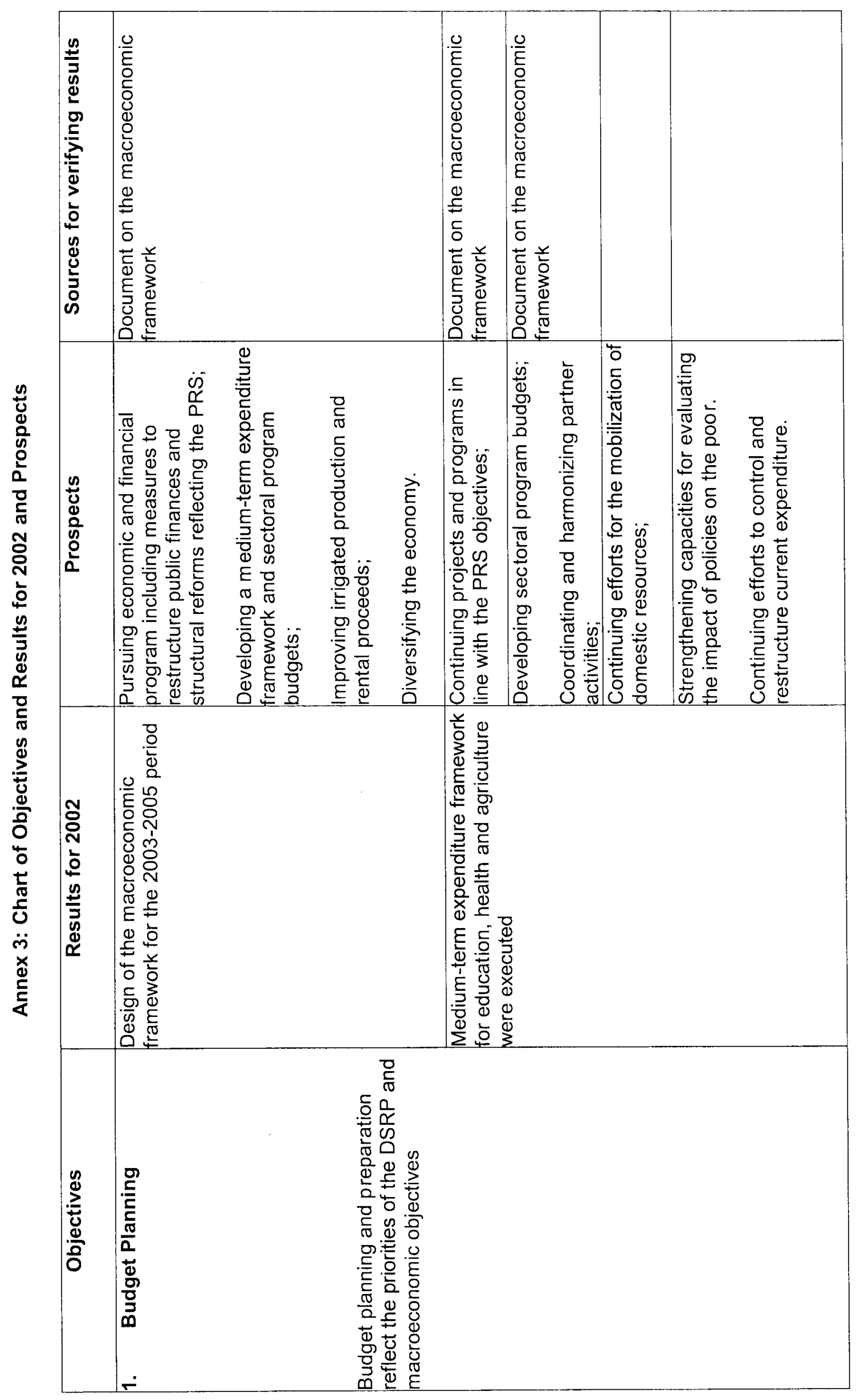




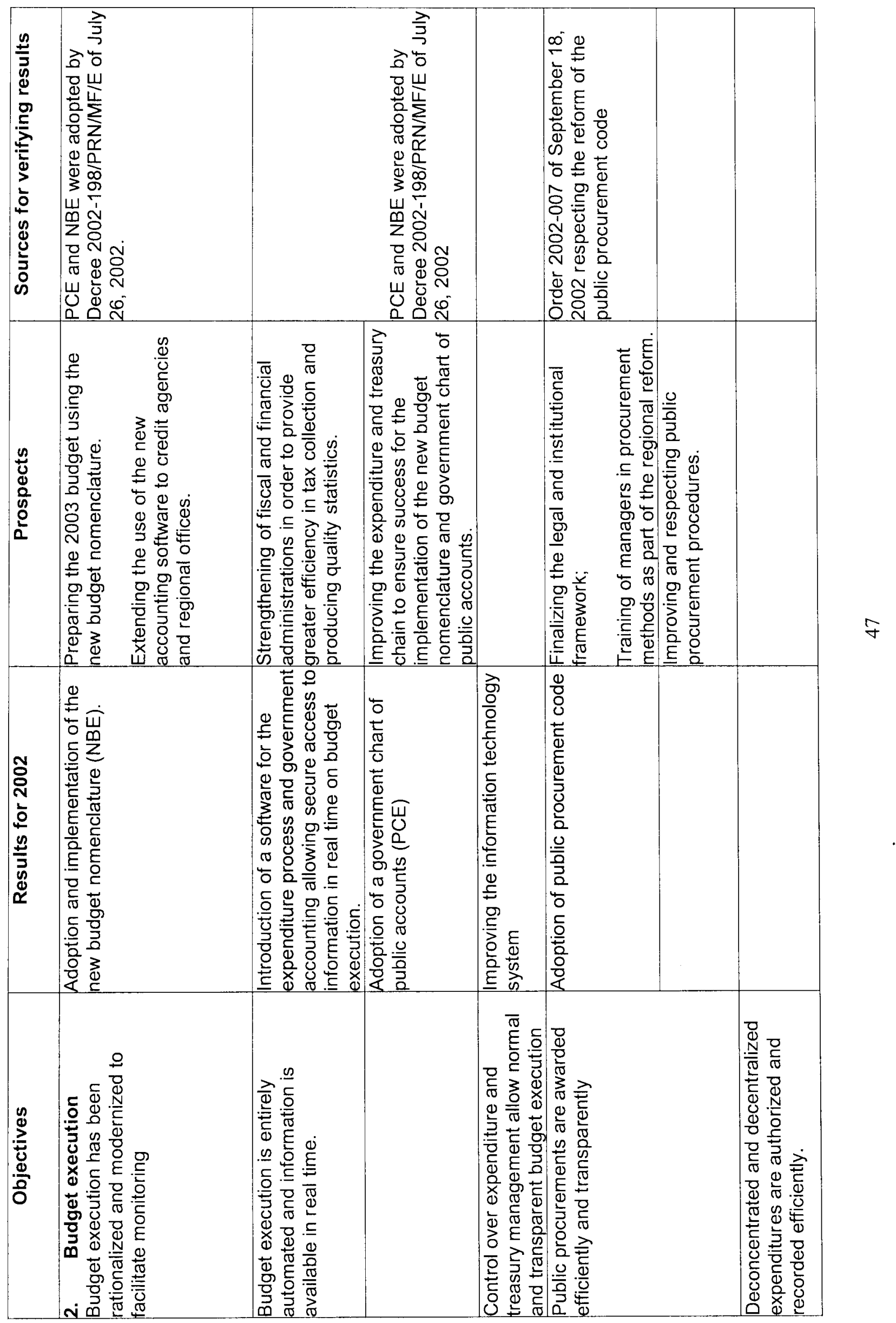




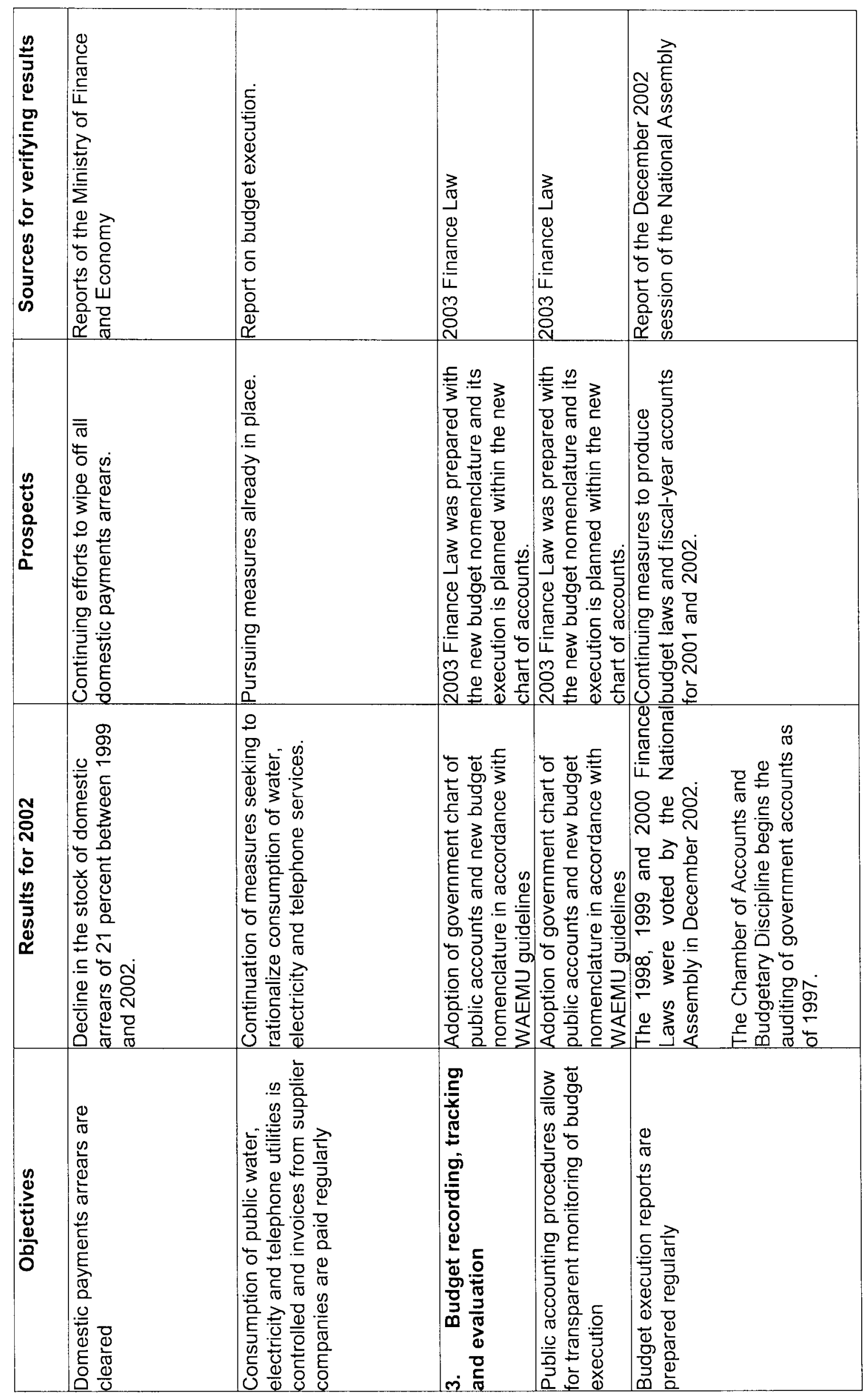




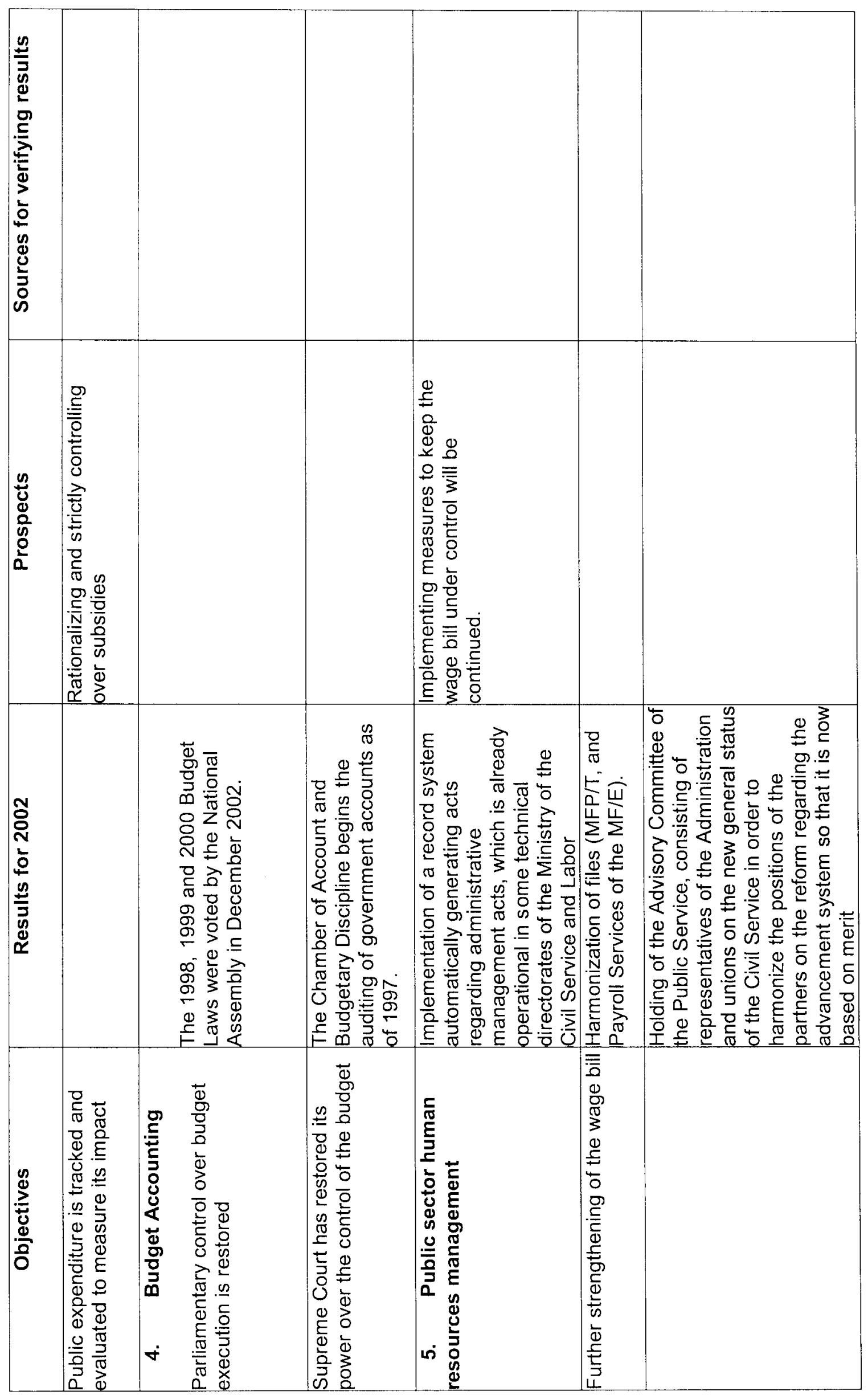




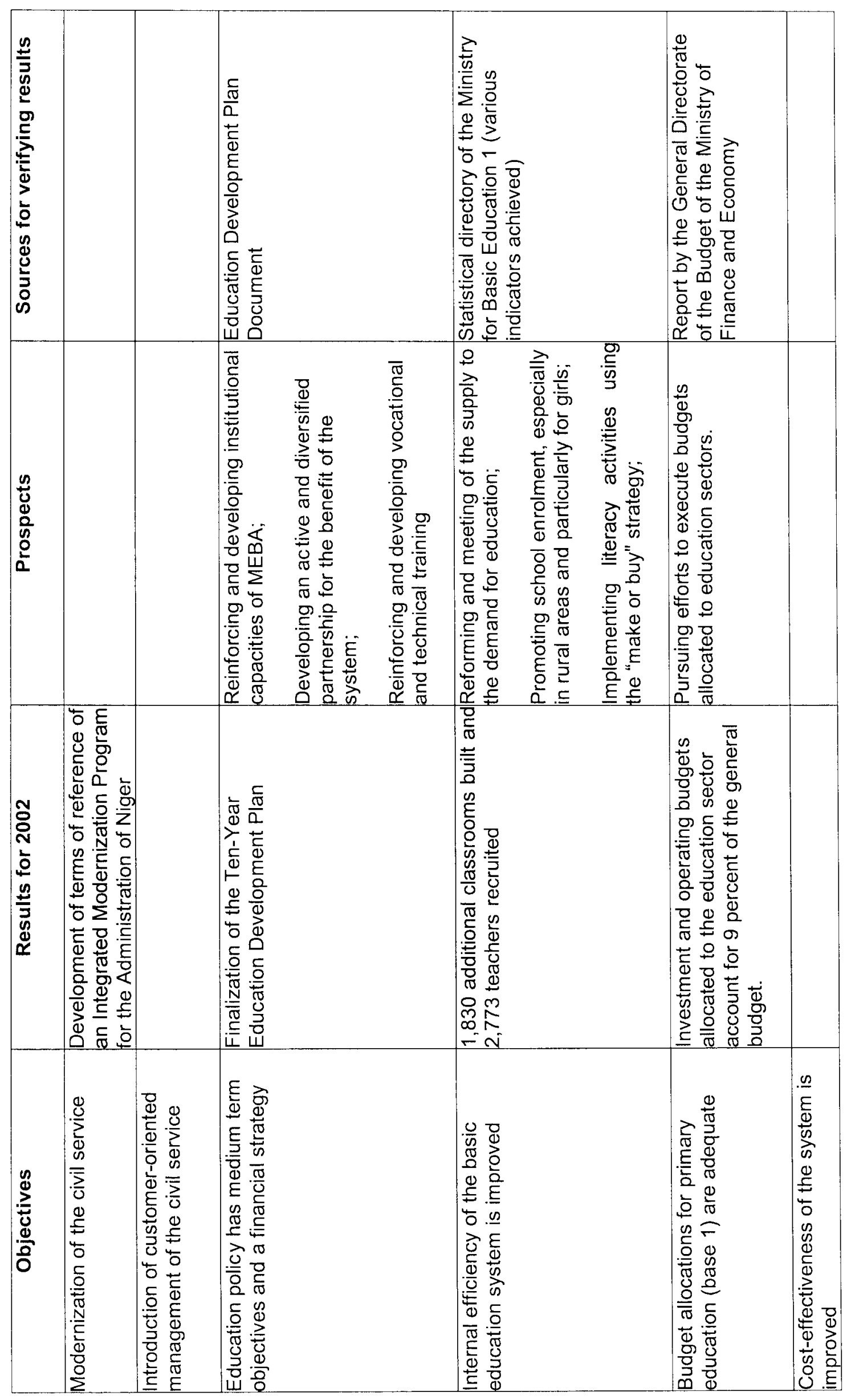




\begin{tabular}{|c|c|c|c|c|c|}
\hline \multicolumn{2}{|c|}{ 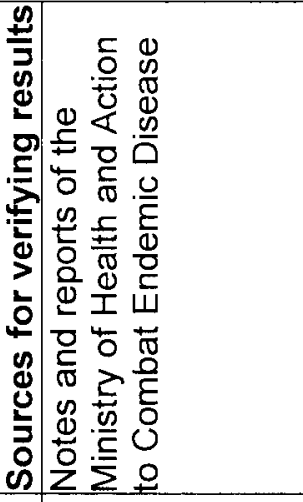 } & 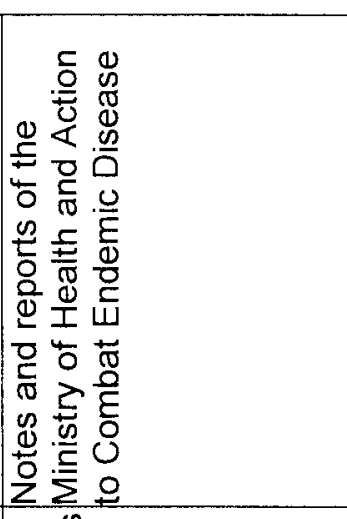 & 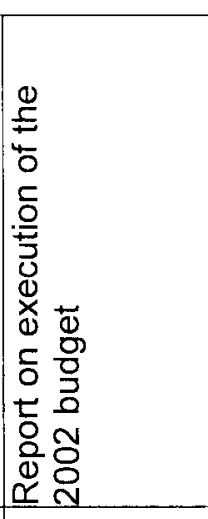 & 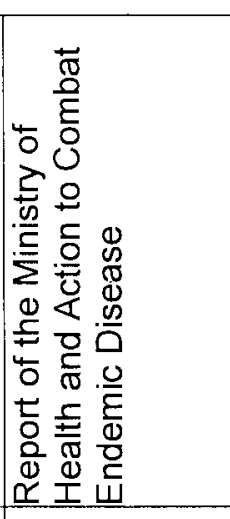 & 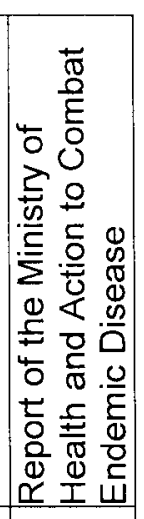 \\
\hline 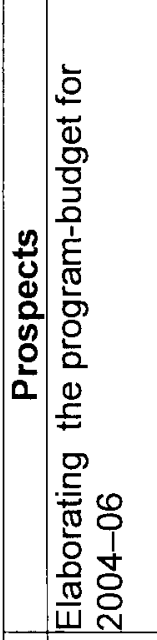 & 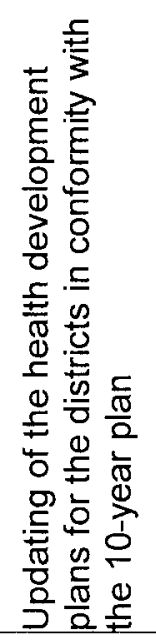 & 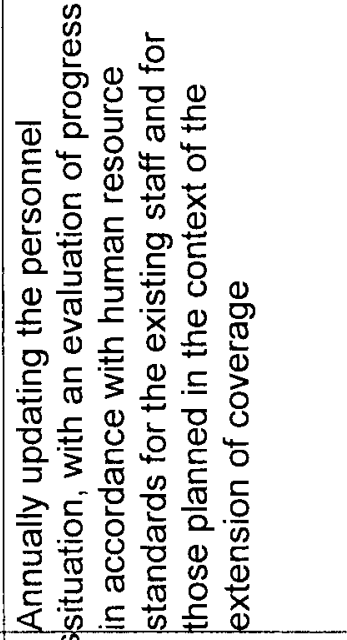 & 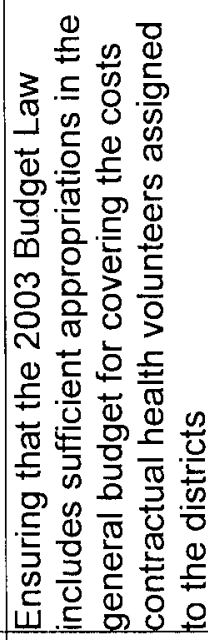 & 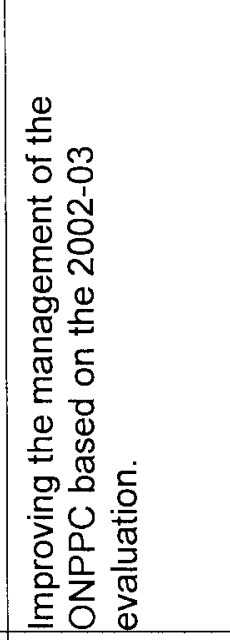 & 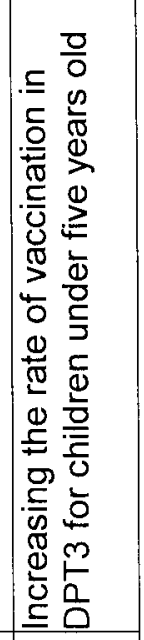 \\
\hline 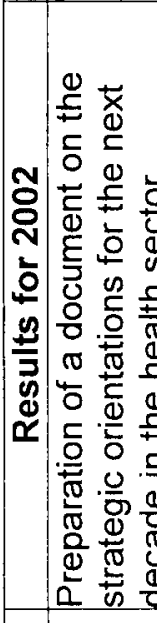 & & 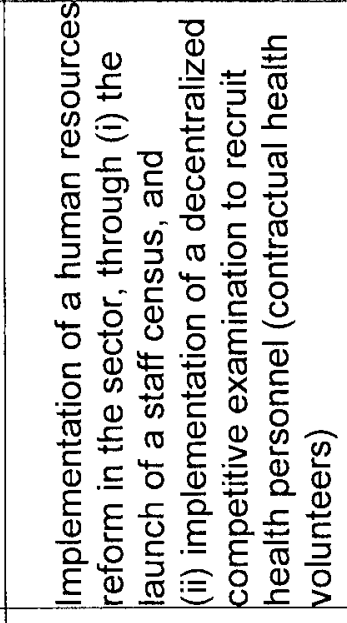 & 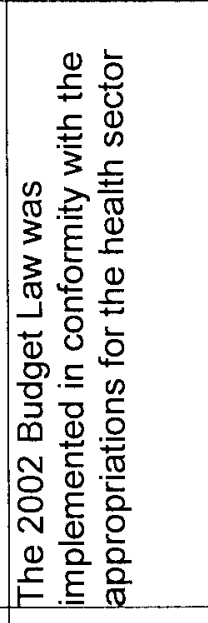 & 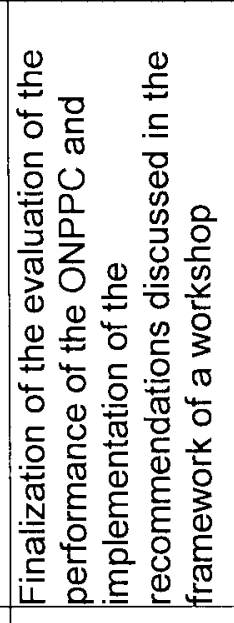 & 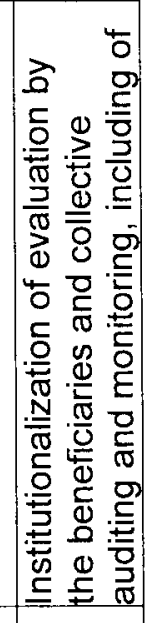 \\
\hline 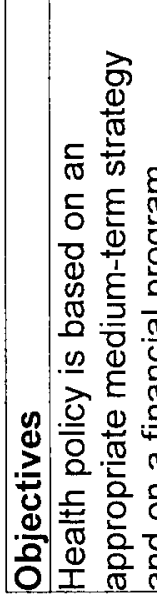 & & 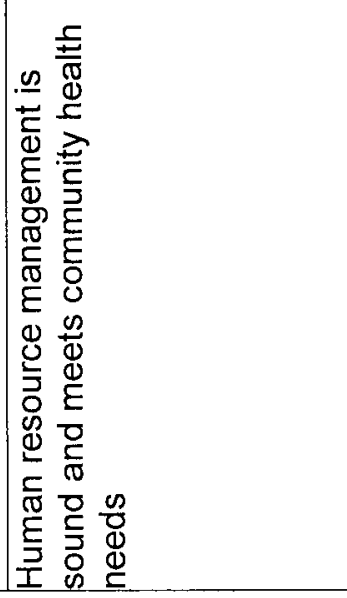 & 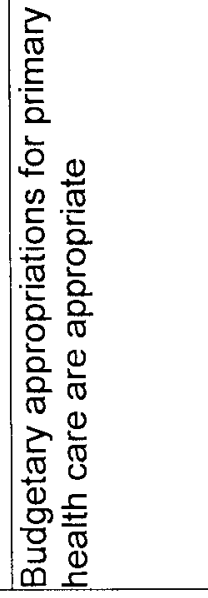 & 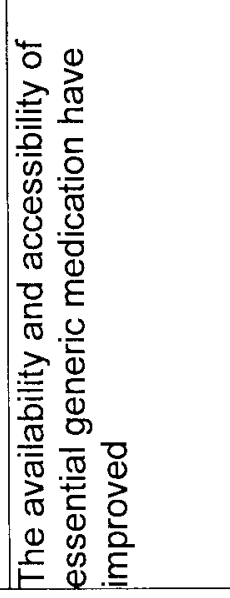 & 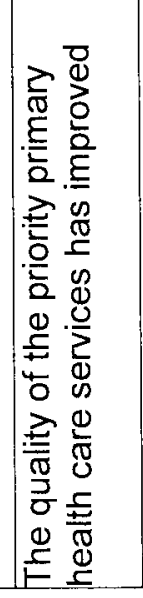 \\
\hline
\end{tabular}




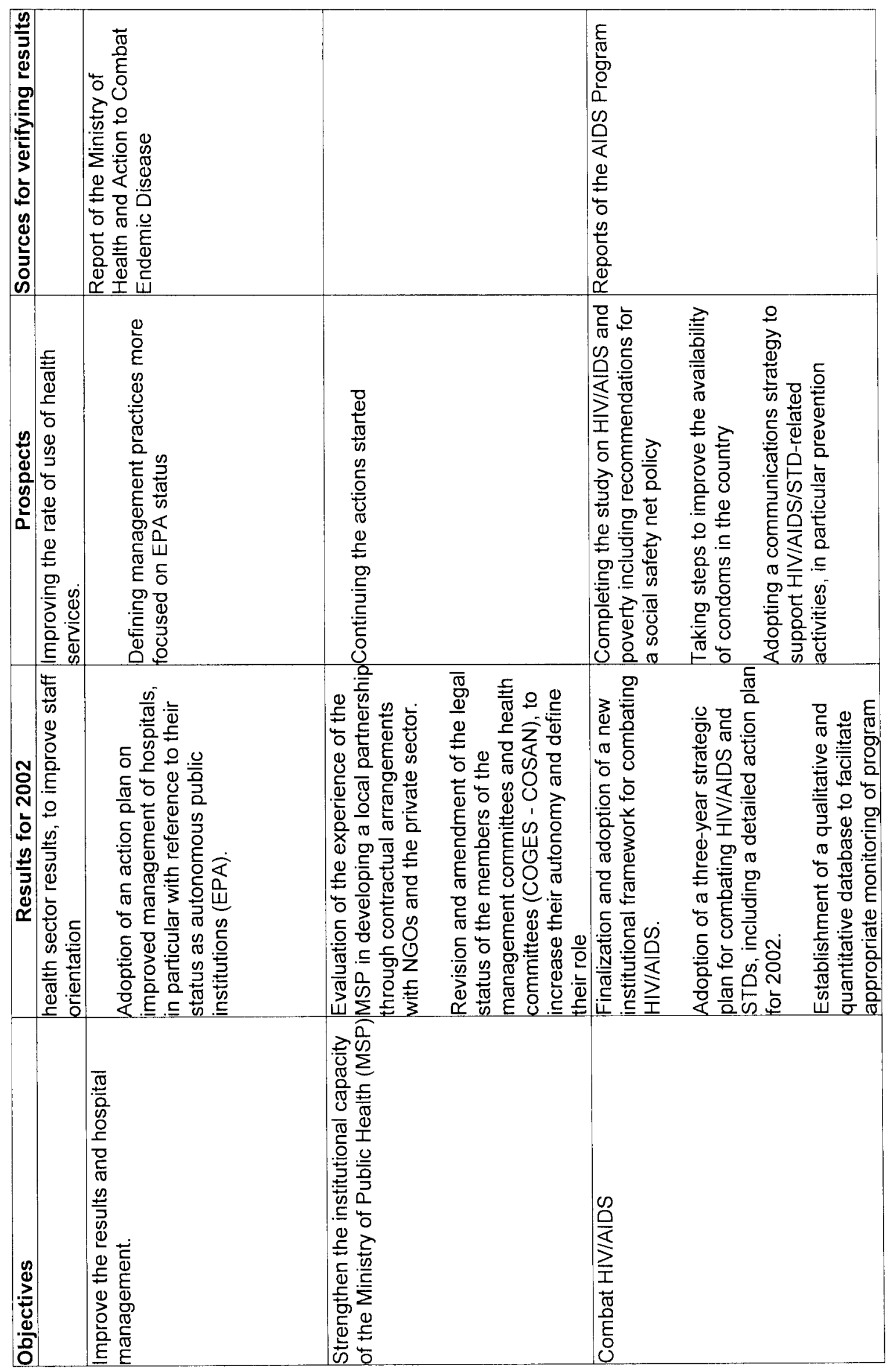

n 


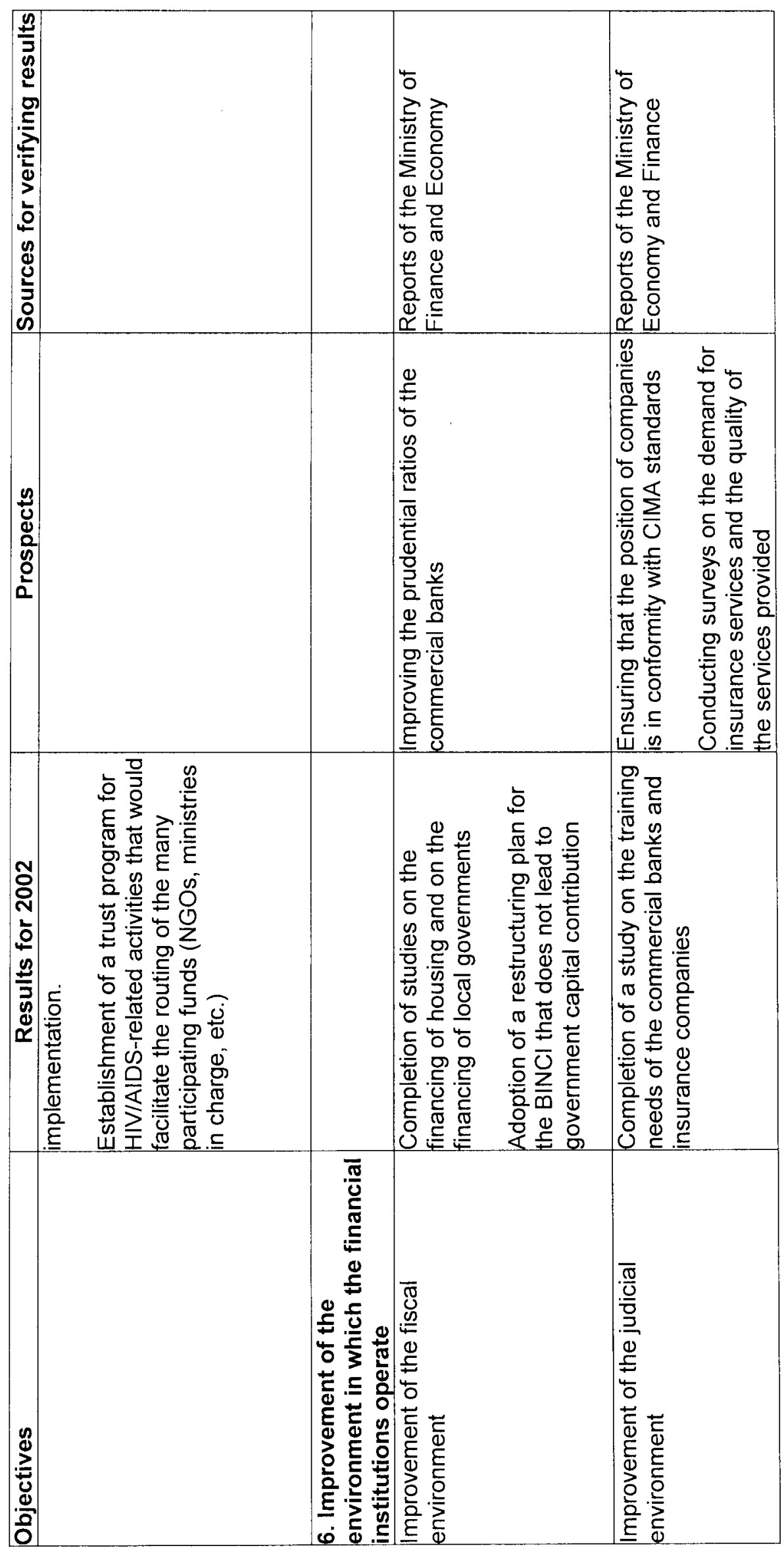

$n$ 

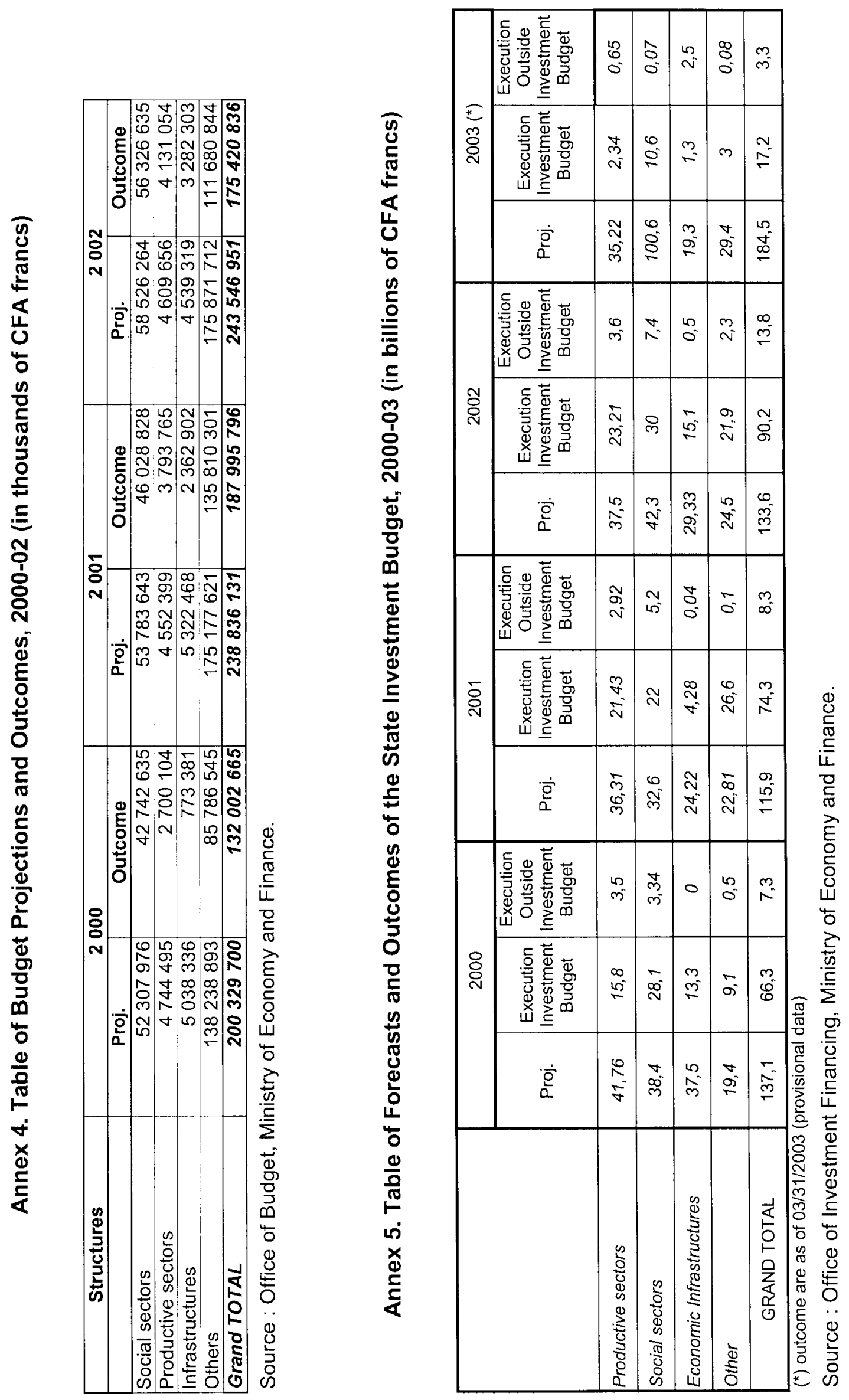